\title{
Genel Aidiyet, Öz-Anlayış, Affetme ve Problem Alanları Gerçek ve Psikolojik Doğum Sırasına Göre Farklılaşır mı? ${ }^{1}$
}

\author{
Sinem ÇAKIR ${ }^{2}$ ve Çiğdem YAVUZ GÜLER ${ }^{3}$
}

Öz

$\mathrm{Bu}$ araştırmada, genel aidiyet, öz-anlayış, kendini affetme ve problem alanlarının bireylerin gerçek ve psikolojik doğum sırasına göre incelenmesi amaçlanmıştır. Araştırmanın örneklemini 18-73 yaş arasında ki katılımcılar olușturmaktadır. Araştırmanın çalışma grubunu; 261’i (\%64.8) kadın, 142’si (\%35.2) erkek olmak üzere 403 birey oluşturmaktadır. Araştırmanın sonuçları Psikolojik doğum sırasına göre ortanca çocuk olan bireylerin, akademik, aile, arkadaşlık, romantik ilişki, cinsellik, uyum ve duygusal problemleri daha fazla yaşadığını göstermektedir. Psikolojik doğum sırasına göre tek çocuk olan bireylerin ise akademik, aile, romantik ilișki, sigara/alkol/madde kullanımı, kișilik ve cinsellik alanlarında daha fazla problem yaşadığı bulunmuștur. Araşıırmada; özanlayış, affetme ve genel aidiyetin gerçek doğum sırasına göre farklılaşmadığı bulunmuştur. Öte yandan Psikolojik doğum sırasına göre ortanca çocukların özanlayış ortalamaları büyük ve küçük çocuklardan; tek çocukların ise özanlayış puan otrtalamaları küçük çocuklardan anlamlı düzeyde düşük bulunmuştur. Bununla birlikte affedicilik açısından Psikolojik Doğum Sırasına göre Büyük Çocukların affedicilik puanlarının tek çocuklardan anlamlı derecede daha yüksek olduğu görülmüştür. Genel aidiyet açısından değerlendirildiğinde; Psikolojik Doğum Sırasına göre büyük çocukların genel aidiyet düzeylerinin, Ortanca ve tek çocuklardan anlamlı derecede daha yüksek küçük çocukların aidiyet düzeylerinin ise ortanca ve tek çocuklardan anlamlı derecede daha yüksek olduğu görülmüştür. Araştırma sonuçları; problem alanları, özanlayış, genel aidiyet ve affetme değişkenleri açısından psikolojik doğum sırasının, gerçek doğum sırasından daha ayırıcı bir değişken olduğunu göstermektedir.

Anabtar Kelimeler: Gerçek Doğum Sırası, Psikolojik Doğum Sırası, Genel Aidiyet, Öz Anlayış, Affetme, Problem Alanları

\section{Do the General Belongingness, Self-Compassion, Forgiveness and Problem Areas Differ According to the Actual and Psychological Birth Order?}

\section{Abstract}

The aim of this study was to examine the areas of general belongingness, self-compassion, self-forgiveness and problem areas according to the actual and psychological birth order of individuals. The sample of the study consisted of participants between the ages of 18-73 $\left(\mathrm{X}^{2}=35.20\right)$. The study group consisted of 403 individuals, $261(64.8 \%)$ of whom were female and $142(35.2 \%)$ were male. Demographic form contained questions about gender, age, education status, actual birth order and problem areas. The results of the study show that psychological middle individuals, experience more academic, family, friendship, romantic relationships and sexuality, adaptation and emotional problems. Psychologically only individuals are found to have more problems in academic, family, romantic relationships, smoking/alcohol/substance use, personality and sexuality areas. In the study, it was found that self-compassion, forgiveness and general belongingness did not differ according to actual birth order. On the other hand, it was also found that according to their psychological birth order, self-compassion score averages of psychologically middle individuals were significantly higher than those of oldest and youngest. Self-compassion score averages of psychologically only individuals were significantly lower than those of youngest individuals. Moreover, it was found that the forgiveness scores of psychologically oldest individuals were significantly higher than those of psychologically only individuals in terms of forgiveness. When evaluated in terms of general belongingness, it was observed that overall belongingness levels of psychologically oldest individuals were significantly higher than those of middle and only individuals, and belongingness levels of psychologically youngest individuals were significantly higher than those of psychologically middle and only individuals. The results of the research show that psychological birth order is more distinctive variable than actual birth order in terms of problem areas, selfcompassion, general belongingness and forgiveness variables.

Key Words: Actual Birth Order, Psychological Birth Order, General Belongingness, Self-Compassion, Forgiveness, Problem Areas

\section{Atıf İçin / Please Cite As:}

Çakır, S. ve Yavuz Güler, Ç. (2021). Genel aidiyet, öz-anlayış, affetme ve problem alanları gerçek ve psikolojik doğum sırasına göre farklılaşır mı? Manas Sosyal Araştırmalar Dergisi, 10(2), 1332-1352.

Geliş Tarihi / Received Date: 21.05.2020

Kabul Tarihi / Accepted Date: 14.01.2021

1 Bu çalıșma ilk yazarın (SC), ikinci yazar (ÇYG) danıșmanlığında yürütülen yüksek lisans tez çalıșmasından üretilmiștir.

2 Uzm Klinik Psikolog - sinemuckardaslar@gmail.com

iD ORCID: 0000-0001-9262-7406

${ }^{3}$ Dr. - Fatih Sultan Mehmet Vakıf Üniversitesi Eğitim Bilimleri Fakültesi, cigdemyavuzguler@gmail.com

(iD ORCID: 0000-0002-1607-0789 


\section{Giriş}

Sir Francis Galton 1874'te ilk doğan erkek çocuklarının bilim adamları arasında fazla temsilinden bahsederek, doğum sırası kavramını psikoloji alanına ilk dahil eden kişi olmuştur (Herrera, Zajonc, Wieczorkowska ve Cichomski, 2003, s. 142-150). Kuramsal temelinin oluşması daha sonraki yıllarda Bireysel Psikolojinin kurucusu Alfred Adler ile başlamış ve günümüze kadar etkinliği devam eden önemli bir kavram olarak psikoloji, sosyoloji ve tıp alanında araştırmalara konu olmuştur. Tüm aile sistemlerinde dünyaya gelen çocukların kronolojik olarak bir doğum sırası vardır. Ancak Adler, bu dünyaya geliş sırasının bir adım ötesine giderek, çocukların içine doğdukları ailede kendilerine ait öznel bir konum belirlediklerini ve yaşam tarzı oluşturmak için bu öznel konumdan yararlanacaklarını belirtmiştir. Özellikle 5 yaşına kadar belirlenen ve bireylerin kişilik gelişimini önemli ölçüde şekillendiren 'yaşam tarzını' değerlendirmek için doğum sırası kavramını sıkça kullanmıştır (Feist ve Feist, 2006). Adler, kardeşlerin dünyaya geliş sırasını ifade eden gerçek doğum sırasının yanısıra başkalarıyla etkileşim içindeyken benimsedikleri rolü ifade eden farklı görevlere ve kişilik özelliklerine sahip 4 konumdan bahsetmektedir (ilk çocuk, ikinci çocuk, ortanca çocuk, küçük çocuk ve tek çocuk) (Shulman ve Mosak, 1977, s. 114-121).

Psikolojik doğum sırası ise, gerçek doğum sırasından bağımsız olarak, çocukların aile içindeki diğer bireylerle etkileşimi sonucunda benimsedikleri doğum sırası konumunu ifade etmektedir ve bu gerçek doğum sırasından farklı olabilmektedir (Stewart ve Campbell, 1998, s. 42-60). Aynı ailede büyüyen çocukların aynı aile ortamına sahip olduğunu düşünmek yanlış olacaktır (Leman, 1997; Sullivan ve Schwebel 1996, s. 55-64). Dünyaya gelen her çocuk ailelerinin sevgi ve ilgisini paylaşmak amacıyla, kendilerini ve içinde bulundukları kardeşlik rollerini tanımlamaya çalışmaktadır (Eckstein ve Kaufman, 2012, s. 60-74). Çocuklar anne ve babalarının gözünde olduğu kadar kardeşlerinin gözünde de önemli olarak görülmek istemektedir ve kardeş grubu içinde kendi özel yerlerini geliştirmeye çalışmaktadır (Gfroerer, Gfroerer, Curlette, White ve Kern, 2003, s. 30-41). Adler ayrica bu rollerin şekillenmesinde, cinsiyet, kardeşler arasındaki mesafe ve aile atmosferinin etkili olduğunu vurgulamaktadır (Campbell, White ve Stewart, 1991, s. 380-391).

Bu bakımdan değerlendirildiğinde gerçek doğum sırası ve psikolojik doğum sırasının farklılaşmasına neden olabilecek bazı koşullar bulunmaktadır. Bireylerin içinde bulundukları her aile sistemi kendine özgü bir yapıya sahip olduğu için boşanma, yeniden birleşme, ölüm, evlat edinme, zihinsel engellilik, kardeş sayısı, kardeşler arasında ki yaş farkı, aile atmosferi gibi pek çok etmen, aile içinde bireylerin gerçek doğum sırasından ziyade psikolojik doğum sırası konumlarını benimsemelerine neden olmaktadır (Leman, 1997). Psikolojik doğum sırası kavramı bu noktada gerçek doğum sırasından ayrılmaktadır ve bireyler üzerinde önemli bir etkiye sahip olduğu görünmektedir (Campbell vd., 1991, s. 380-391; Lohman, J.F., Lohman, T.G. ve Christensen 1985, s. 313-327).

\section{Doğum Sırasına İlişkin Nitelikler}

Genel özelliklerine bakıldığında büyük çocuklar başkalarının bakım ve ihtiyaçları ile ilgilenen, iyi organize olabilen, çok endişeli bir yapıya sahip olmaları muhtemel olan bireylerdir. Ayrıca büyük çocuklar çoğunlukla kendilerinin haklı olduğu, diğerlerinin yanıldığı düşünceleri ile baş başa kalmaktadır. Kabul için savaşırlar ve bilinçsiz düşmanlık besleyebilirler. Abartılı güç ve üstünlük duyguları onları işbirlikçi olmayan kişi pozisyonuna sokabilmektedir (Feist ve Feist, 2006). Akademik başarısı yüksek ve akademik problemlerle en az uğraşan çocuklar genellikle ilk çocuklardır. Ayrıca öğretim üyeleri gibi öğrenim grupları arasında fazlasıyla temsil edilmektedirler. Başarı ihtiyaçları fazladır ve yüksek motivasyonludurlar. Stresli durumlarda etkin çözüm becerisine sahip olurlar. Liderlik özellikleri ön planda yer almaktadır ( Eckstein, 2000, s. 481-494 ; Eckstein vd., 2010, s. 408-434). Sulloway (1997), kişilik özellikleri bakımından ilk çocukları; anne ve baba kıskançlığı yaşamaya müsait, nevrotik, organize ve planlı, öz güveni yüksek, dışa dönük ama aynı zamanda sosyal mesafeye önem veren, lider ruhlu, daha geleneksel, endişeli, iddalı ve başarı odaklı kişiler olarak tanımlamaktadır. Ayrıca aileden en çok yatırımı alan yine ilk çocuklar olmaktadır.

Ortanca çocuklar, ailedeki önemini bulmak için zor zamanlardan geçmektedir (Gustafson, 2010). En fazla ait olamama hissi ortanca çocuklarda görülmektedir (Eckstein, 2000, s. 481-494). Yaşlı ve genç insanlarla iyi ilişskiler geliştiren, sosyal ve girişken bireylerdir. Bunun yanı sıra takım oyunlarında yüksek başarı oranı görülmektedir. Ayrıca romantik ilisskilerde sadık olma eğilimleri fazladır (Eckstein vd., 2010, s. 408-434). İlk çocuğun denemediği alanda rekabetçi olma eğilimine sahiptirler ve ilk çocuğun görmezden geldiği alandaki konulara odaklanmayı tercih ederler (Carlson, Watts ve Maniacci, 2006; Eckstein vd., 2010, 
s. 408-434) Ailenin ortancası olmak aynı zamanda onları aile içi çatışmalarda daha müzakereci ve barış yanlısı olmaya itmektedir (Gustafson, 2010). Ortanca çocuklar oldukça sosyaldir ve geniş arkadaş çevresine sahiptir. Ayrıca evden genellikle ilk ayrılan yine ortanca çocuklar olmaktadır (Leman, 1997).

Küçük çocukların genel özellikleri, şımartılmış yaşam tarzı geliştirmiş, başkalarına bağlı, zaman zaman gerçek dışı iddalı bireyler olmalarıdır (Feist ve Feist, 2006). Psikiyatrik bozukluk görülme ihtimali özellikle küçük ailede yetişmişlerse diğer doğum sıralarına göre daha fazla olmaktadır. Alkol ve madde kötüye kullanım eğilimleri yine diğerlerine oranla daha fazla olabilmektedir (Eckstein, 2000, s. 481-494). Ayrıca sosyal yönden en çok kabul gören ve ilgi alan grup küçük çocuklardır. Asilik özelliği daha fazla görülmektedir. Yazarlar arasında yüksek temsil oranına sahiptirler ve bilimsellik yerine daha sanatsal eğilimlere sahiptirler. Bunlara ek olarak empati kurma yeteneği kuvvetlidir (Eckstein vd., 2010, s. 408-434).

Adler'e göre tek çocuklar, diğer doğum sıralarından farklı olarak, rekabet duygusunu anne ve babaya yöneltmektedir. Yetişsin bir dünyada kendilerine yer bulmak için yine yetişkin davranışlarını referans alırlar ve abartılı bir üstünlük çabası içine girebilirler. Genel özellikleri, sosyal olarak olgun, düşük işbirliği duyguları olan, şımartılmış yaşam tarzı geliştirmiş, işbirlikçi olmayan bireyler olmalarıdır (Feist ve Feist, 2006). Başarıya en çok ihtiyaç duyanlar tek çocuklardır ve üniversiteye gitme olasıllğı en fazla olanlar yine tek çocuk grubudur (Eckstein, 2000, s. 481-494). Davranış problemleri gösterebilirler ve bir gruba üye olma ihtiyacı en düşük olanlar yine tek çocuklardır. Bencil olabilirler ve ilk çocuklardan sonra en yüksek akademik başarıya sahiptirler (Eckstein vd., 2010, s. 408-434). Bu özellikler doğrultusunda bakıldığında her bir doğum sırasının farklı alanlarda daha fazla problem yaşıyor olması muhtemel gözükmektedir.

\section{Doğum Sırası, Kişiler Arası İlişkiler ve Problemli Durumlara Verilen Tepkiler}

Kişilik karakterden farklı olarak çevrenin etkisiyle oluşur ve yaşam deneyimlerinden beslenir. Bu çevre, çocukların anne ve babalarından aldıkları tüm ilgi, alaka, özveri ve anlayışın beklentilerle karmasından oluşmaktadır (Leman, 1997). Adler, genel olarak teorisinde insanların sosyal çıkarlar yönünde faaliyetlerde bulunduklarını ve davranışlarının arkasındaki dinamiğin ise güç, başarı ve üstünlük çabasından meydana geldiğini söylemektedir (Feist ve Feist, 2006). Bu çaba ilk aile içinde başlamakta ve bir nevi kardeşler arasında üstünlük ve güç mücadelesi yaşanmaktadır. Öznel algısında asla abisi kadar iyi olamayacağına ve kardeşi kadar sevilen olmayacağına inanmış bir ortanca çocuk, yetişkinlikte de bu algiların izlerini taşıyabilir.

Adler bunu 'insanların doğru olanla değil, doğru olanla ilgili öznel algılarıyla motive olurlar’ ifadesiyle açıklamaktadır (Feist ve Feist, 2006). Yani bireyler çocukluk yaşamlarında aile içinde edindikleri öznel algılarla yaşam tarzını inşa ederler ve yetişkinlikte kişilerarası ilişkilerde bu yaşam tarzı korunmaya devam etmektedir (Corey, 2015). Yapılan araştırmalar, doğum sırasının kardeş rekabeti (Sulloway, 2001, s. 39-83), kişiler arası ilişkiler (Salmon, 2003, s. 73-88), romantik ilişsi ve yakın arkadaş tercihleri (Harthsorne, SalemHarthsorne ve Harthsorne, 2009, s. 156-176); irrasyonel ilişki inançları (Kalkan 2008, s. 455-466; White, Campbell, Stewart, Davies ve Pilkington, 1997, s. 89-104) gibi birçok ilişki değişkeni üzerinde etkili olduğunu göstermektedir. Örneğin bir araştırma kişilerarası ilişkilerin gelişmesinde doğum sırasına göre son çocuk olmanın avantajlı olduğunu göstermektedir (Ickes ve Turner, 1983, s. 210-222).

Bireylerin problemlere yönelik başa çıkma tarzları yine doğum sırasına göre farklılaşmaktadır ve buna bağlı olarak farklı doğum sırasından olan bireylerin kişiler arası ilişkilerinin şekillenmesi de farklılaşmaktadır. Kalkan ve Koç ( 2007, s. 45-59)'de gerçekleştirdikleri başa çıkma tutumları ile psikolojik doğum sırası arasındaki ilişkiyi yordamayı amaçlayan araştırma bulgularına göre, büyük çocuklar problemlere yönelik pasif başa çıkma stratejilerini kullanmak yerine daha aktif ve çözüm odaklı başa çıkma stratejilerini kullanma eğiliminde olmaktadırlar. Ortanca çocukların ise daha çok boyun eğici, güçsüz ve çaresiz yaklaşımları problemlerle başa çımak için kullandıkları görülmektedir. Küçük çocuklarda aile içindeki konumları itibariyle daha korunaklı bir pozisyonda olmaları nedeniyle, pasif ve kabul edici yaklaşımları kullanma eğiliminde oldukları görülmektedir ve genellikle problemler karşısında daha kolay vazgeçmektedirler. Tek çocuklar kendi sorumluluklarının ailesi tarafindan alınmasına alışık oluşlarıyla, problemler karşısında pasifleşerek, boyun eğici ve kaçınmacı stratejileri kullanan bireyler olarak karakterize olmaktadırlar. Ayrıca büyük çocuklar akademik, ekonomik problemlerle en az uğraşan doğum sırasıdır (Eckstein vd., 2010, s. 408-434). Ortanca ve tek çocukların ise romantik ilişkilerde ve kıskançlık duygusuyla ilgili alanlarda, diğer doğum sırası pozisyonlarından daha fazla problem yaşayabilecekleri belirtilmektedir (Buunk, 1997, s. 997-1006; McGurik ve Pettijohn II, 2008, s. 37-52). Ayrica en fazla ait olamama duygusu ortanca çocuklarda görülmektedir (Eckstein, 2000, s. 481-494). Özellikle düşük aidiyet duygusunun, bireylerde mutsuzluğa, düşük benlik saygısı, yalnızlık ve depresyon gibi psikolojik işlevlerin kaybıyla ilişkili 
olduğunu gösteren çalışmalar mevcuttur (Andersen, Chen ve Carter, 2000, s.269-275; Duru, 2015, s. 37-47 Hill, 2006, s. 210-216; Osterman, 2000, s. 323-367).

Dışadönüklük ise yüksek aidiyet duygularıyla ilişkili bir kişilik özelliğidir (Malone, Pillow ve Osman, 2012, s. 311-316). Hem aile desteğini en az hisseden (Pilkington, White ve Matheney, 1997, s. 42-57) hem de aidiyet duygusu en az olan ortancalar için kişilik yönünden problem yaşamaları muhtemel görülmektedir. Tek çocuklar doğum sırası pozisyonları içinde en bencil olan konumdur (Eckstein vd., 2010, s. 408-434) ve bu yönleriyle tek çocuklar kaçınma stratejilerini kullanan bireylerdir ve yok sayma, görmezden gelme, uzaklaşma gibi problemin kaynağından sadece uzaklaşmalarını sağlayan başa çıkma tutumlarını sıkça kullanmaktadırlar (Kalkan ve Koç, 2007, s. 45-59). Bunun yanı sıra madde kullanımı için büyük çocuk doğum sırasının koruyucu bir faktör olduğu (Horner, Andrade, Delva, Grogan-Kaylor ve Castillo, 1998, s. 19-37) ve son doğan çocukların ilk doğanlara oranla daha fazla alkol kullandıkları (Laird ve Shelton, 2006, s. 18-35) literatürde yer alan bir kaç araştırmaya örnektir. Kendisinden büyük bir kardeşe sahip olan bireylerin suç eğilimli davranışlar sergilemeleri (çalma gibi), ya da alkol madde kullanma ihtimalleri büyük çocuklardan fazla olduğu belirtilmektedir (Argys, Rees, Averett ve Witoonchart , 2006, s. 215-233). Son olarak ailevi problemleri psikolojik doğum sırası büyük, ortanca ve tek çocuk olan bireyler, psikolojik doğum sırası küçük çocuk olan bireylerden daha fazla yaşamaktadır (Salmon, 2003, s. 73-88; Salmon ve Daly, 1998, s. 299-312). Bu bağlamda değerlendirildiğinde problem alanlarının psikolojik doğum sırasına göre farklılaşması beklenmektedir.

Öz anlayış, aynı zamanda hayatta karşımıza çıkabilecek olumsuz durumlara yönelik negatif duygu üretilse bile bunu şefkatle kabul ederek yeni olumlu duygular üretilmesini sağlayan önemli bir öz tutumdur (Germer ve Neff, 2013, s. 856-867). Öz anlayışlı bireyler başarısızlıktan daha az korkarlar (Neff, Hsieh ve Dejitterat, 2005, s. 263-287). Öz anlayışlı bireyler sergiledikleri performansları kişiselleştirmeden değerlendirebilen, gerçekçi değerlendirme yapabilen bireylerdir (Neff vd., 2005, s. 263-287). Öz anlayış, bireylerin kişiler arası ilişkilerini ve yaşam amacını etkileyen önemli bir öz tutumdur. Bireylerin ortaya çıkabilecek olan her türlü negatif duruma ya da olumsuzluğa karşı 'anlayış' gösterebilmesiyle ve bu 'anlayış’ı́n yönüyle ilgilenmektedir (Neff, 2003a, s. 85-101; 2003b, s. 223-250). Öz-anlayış kavram1 3 temel öğeye ayılmaktadır: öz-şefkat (self-kindness), (b) ortak insanlık / paydaşım (common humanity), (c) bilinçli farkındalık (mindfulness) (Neff, 2003a, s. 85-101; Özyesil, 2011).

Etrafımızdaki insanların yaşadıkları zorluklara karşı göstermiş olduğumuz onarıcı, kabullenici yönümüzün kendimize karşı daha acımasız ve eleştirel olduğundan bahseden Neff, öz anlayış kavramını psikolojik iyi oluşla yakından ilişkilendirmektedir. Bu bağlamda "Öz şefkat"; öz yargıllamanın, izolasyonun ve ruminasyonun (depresyon gibi) olumsuz sonuçlarına karşı bireyleri koruyan pozitif duygusal tutumu ifade eder (Neff 2003a, s. 85-101). "Ortak paydaşım"; İnsanoğlunun kusurlu olduğunu ve herkes gibi ac1 çekebileceğimizi kabul etmektir. (Germer ve Neff, 2013, s. 856-867; Neff 2003a, s. 85-101). "Bilinçli farkındalık"; acı verici düşünce ve duygularımıza yönelttiğimiz dikkati ifade eder. Acıdan kurtulmak amacıyla yaşanılan duygu ve düşünceleri farketmeden harekete geçmek bizi şefkatten uzaklaştırmaktadır (Germer ve Neff, 2013, s. 856-867; Neff 2003a, s. 85-101).

Yapılan araştırmalar öz anlayış ile yaşam doyumu, sosyal bağ, duygusal zeka, mutluluk, refah arasında pozitif ilişki olduğunu gösterirken, kayg1, depresyon, utanç, başarısızlık korkusu ve tükenmişlik ile negatif ilişskili olduğunu göstermektedir (Bernard ve Curry, 2011, s. 289-303; Mills, Gilbert, Bellew, McEwan ve Gale, 2007, s. 358-364; Neff vd., 2005, s. 263-287; Neff ve Mcgeehee, 2010, s. 225-240; Neff, Rude ve Kirkpatrick, 2007, s. 908-916; Williams, Stark ve Foster, 2008, s. 37-44). Ayrıca öz anlayış ustalık hedefleriyle, duygularla, bireylerin etkileşim şekilleriyle pozitif yönde ilişkilidir ve performans hedefleri, başarısızlık durumuna ilişkin kişilerin gösterdikleri tutumlarla, uyumsuz başa çıkma stratejileriyle, uyumsuz mükemmelliyetçilikle, düşünce baskılama ve ruminasyonla negatif yönde ilişkili bulunmuş oldukça önemli bir öz tutumdur (Leary, Tate, Adams, Allen ve Hancock, 2007, s. 887-904; Neff vd., 2005, s. 263-287; Neff, 2003a, s. 85-101; Williams vd., 2008, s. 37-44; Thompson ve Waltz, 2008, s. 556-558) Özellikle ailelerin yaklaşım şekli çocukların iç diyaloglarına yansıyarak, öz anlayışı etkilemektedir (Neff ve Mcgeehee, 2010, s. 225-240).

Problemli durumlarla başa çıabilme gücünü arttıran değişkenlerden bir diğeri de affetmedir. Affetme hem içsel hem de kişilerarası bir dinamik olarak değerlendirilebilir. Kendini affetme, bireylerin mevcut hataları veya başkasına vermiş oldukları bir zarar karşısında kendilerini cezalandırmak yerine, kendilerini kabul etme motivasyonuna sahip olabilmelerini ifade eden önemli bir kavramdır (Hall ve Fincham, 2005, s. 621-637). Kendini affetme, hem öz anlayış kavramıyla (Neff ve Pommier, 2013, s. 160-176), hem de başa 
çıkma tutumlarıyla (Worthington Jr. ve Scherer, 2004, s. 385-405) yakından ilgili olduğu vurgulanan ve bireylerin kişiler arası ilişkilerinin düzenlenmesinde rol alan önemli bir öz nitelik olarak karşımıza çıkmaktadır. Özellikle affetme yakın ilişkilerde daha da önemli bir durum ortaya koymaktadır. Psikolojik iyi oluş ile yakından ilişkili olan affetme, bireylerin yakın ilişkilerde yaşayabilecekleri ambivalans duyguların getireceği psikolojik gerginlikten korunmalarına yardımcı olmaktadır ve kişinin öz iyiliği için gereklidir (Bono ve McCullough, 2006, s. 147-158).

$\mathrm{Bu}$ araştırmada öncelikle bireylerin gerçek doğum sırasının psikolojik doğum sırası ile ilişkileri belirlenmeye çalısıllmış, bir diğer deyişle gerçekte aile sisteminde var olan doğum sırasını psikolojik açıdan da koruyup korumadığı incelenmiştir. Sonrasında; bireylerin problem yaşadıkları alanların gerçek doğum sırası ve psikolojik doğum sırasına göre farklılaşıp farklılaşmadığının incelemesi amaçlanmıştır. Bununla birlikte, bireylerin özellikle kişilerarası ilişkilerde karşılaştıkları problemlerle baş etme stratejilerinin gerçek ve psikolojik doğum sırasına göre farklılaşacağı varsayılmaktadır. $\mathrm{Bu}$ sebeple çalışmanın temel amaçlarından bir diğeri de öz anlayış, genel aidiyet ve affetmenin gerçek ve psikolojik doğum sırasına göre farklılaşıp farklılaşmadı̆̆ını ortaya koymaktır.

\section{Yöntem}

Araştırma, nicel araştırma metodunun ilişkisel tarama yöntemi kullanılarak yapılmıştır. Araştırmada, katılımcıların demografik bilgilerinin edinilmesi amacıyla araştırmacılar tarafından oluşturulan Kişisel Bilgi Formu, White-Campbell Psikolojik Doğum Sırası Envanteri, Genel Öz Anlayış Ölçeği Aidiyet Ölçeği ve Heartland Affetme Ölçeği kullanılmıştır. Araştırmadan elde edilen veriler, SPSS 22, bilgisayar programı kullanılarak analiz edilmiştir.

\section{Çalışma Grubu}

$\mathrm{Bu}$ araştırmanın çalışma grubunu; araştırmaya gönüllü katılmayı kabul eden 403 katılımcı oluşturmuştur. Çalışma Grubunun 261’i (\% 64.8) kadın, 142’si (\% 35.2) erkektir. Öğrenim durumu değişkeninde; ortaokul mezunları $\% 5$, Lise mezunları \% 14.4, Üniversite mezunları \%60 ve Lisans üstü mezunlar \% 20.6'sını oluşturmaktadır. Çalışma grubunun gerçek doğum sıraları incelendiğinde; \% 33.7 Büyük çocuk, \% 21.1 ortanca çocuk, $\% 38.2$ son çocuk ve \% 6.9'nun tek çocuk olduğu görülmüştür. Tüm grubun yaş ortalaması 35.20 'dir.

\section{Veri Toplama Araçları}

Kişisel Bilgi Formu. Kişisel bilgi formunun ilk kısmında cinsiyet, yaş, öğrenim durumu ve gerçek doğum sırası ilişkin sorular bulunmaktadır. Formun ikinci kısmında bireylerin problem alanlarının belirlenmesine yönelik 10 soru yer almaktadır. Bu kısımda katılımcılardan tüm hayatlarını dikkate alarak geçmişte yaşadıkları ve belirli bir süre etkili olduğunu düşündükleri problemleri işaretlemeleri istenmiştir. Formda yer alan problem alanları sırasıyla; akademik, aile, arkadaş, ekonomik, romantik ilişkiler, duygusal alan, kişilik alanı, cinsellik, sigara/madde/alkol kullanımı ve uyum alanını kapsamaktadır.

White-Campbell Psikolojik Doğum Sirası Envanteri. White, Campbell ve Stewart tarafindan bireyin psikolojik doğum sırasını belirlemek amacıyla 1991 yılında geliştirilmiş, 1998 yılında revize edilerek son şekli verilmiştir. Ölçeğin Türkçeye uyarlaması Kalkan (2005, s. 169-174) tarafindan yapilmıştır. Büyük Çocuk (Memnun edici/Düzenleyici), Ortanca Çocuk (Dışlanmış/İhmal edilmiş), Küçük Çocuk (Sevimli/İkna edici ve Tek Çocuk (Dikkatle bakılan/Üzerine Titrenilen) olmak üzere dört alt boyuttan oluşan 42 maddelik ölçeğin kadınlar ve erkekler için ayrı puanlama sistemi vardır. Tekrar test güvenirliği kadınlar için.78 ile .89 arasında değişirken, erkekler için ise .77 ile .89 arasında bulunmuştur. İç tutarlık güvenirliği ise kadınlar için .74 erkekler için .86 arasında değişen; erkekler için ise .65 ile .82 arasında hesaplanmıştır (Kalkan, 2005, s. 169-1749).

Genel Öz Anlayıs Ölçeği. Öz-anlayış ölçeğinin orijinali 26 madde 6 alt ölçekten oluşmaktadır. Ölçekte cevaplayanlardan belirtilen durumla ilgili olarak ne kadar sıklıkla hareket ettiklerini 5'li likert tipi bir ölçekte derecelendirmeleri istenmektedir. Neff (2003b, s. 223-250) tarafından geliştirilen Öz-anlayış ölçeğinin Türkçe güvenirlik ve geçerlik çalışması Deniz, Kesici ve Sümer (2008, s. 1151-1160) tarafindan yapılmıştır. Türkçe Öz-Anlayış Ölçeği’nin oriijinalinden farklı olarak ölçeğin tek boyutlu bir yapı gösterdiği ve aynı zamanda madde toplam korelasyonunda $.30^{\prime}$ altında olan 2 tane madde ölçekten çıkartılarak toplam 24 maddelik bir ölçek elde edilmiştir. Ayrıca iç tutarlılık kat sayısı .89 ve test-tekrar test korelasyonu .83 olarak hesaplanmıştır (Deniz vd., 2008, s. 1151-1160). 
Aidiyet Ölçeği. Malone vd. (2012, s. 311-316) tarafindan geliştirilen Genel Aidiyet Ölçeğìnin (GAÖ) ; Türkçe uyarlaması, geçerlik ve güvenirlik çalışmaları Duru (2015, s. 37-47) tarafindan yapılmıştır. Ölçeğin yapısıyla ilgili açımlayıcı faktör analizi sonuçları ölçeğin, Kabul edilme/İçerilme ve Reddedilme/ Dışlanma olmak üzere birbirileriyle negatif yönde ilişkili iki alt boyuttan oluştuğunu göstermiştir. İki alt boyut arasındaki korelasyon katsayısı -.64'dür. Genel Aidiyet Ölçeği'nin iç tutarlılık katsayısı .92 olarak bulunmuştur. Kabul edilme/İçerilme alt ölçeğinin iç tutarllilı katsayısı .89, Reddedilme/ Dişlanma ölçeğinin iç tutarllılk katsayısı ise .91.'dir (Duru, 2015, s. 37-47).

Heartland Affetme Ölceğg. Thompson vd. (2005, s. 313-360) tarafindan bireylerin affetme eğilimlerini ölçmek amacıyla geliştirilen Heartland Affetme Ölçeği (HAÖ) yedili likert tipi $(1=$ beni hiç yansıtmıyor, $7=$ beni tamamen yansıtıyor) arasında değişen on sekiz maddelik bir ölçektir. Ölçeğin kendini, başkasını ve durumu affetme olmak üzere üç alt boyutu bulunmaktadır. Her bir alt boyuttan alınan yüksek puanlar o alandaki yüksek affetme düzeyini yansıtmaktadır. Ölçek toplam affetme puanını da vermektedir. Bireylerin, ölçekten aldığ toplam affetme puanı "genel affetme" olarak adlandırllmıştır. Heartland Affetme Ölçeği(HAÖ)'nin orjinalinin geçerlik ve güvenirliği için yapılan çalsşmalar sonucunda, test tekrar test katsayısı kendini affetme alt boyutu için .83 , başkasını affetme için .72, durumu affetme alt boyutu için .73 ve toplam puan için .77 olarak hesaplanmıştır. Cronbach $\alpha$ katsayıları da sırasıyla $.75, .78, .79$ ve toplam puan için .86 olarak rapor edilmiştir. Ölçeğin Türkçeye uyarlama çalışması Bugay ve Demir (2010) tarafindan yapılmıştır. Ölçeğin alt testleri için Cronbach alfa değerleri sırasıyla kendi affetme için, .64; başkalarını affetme için, .79 ve durumu affetme için, .76 olarak bulunmuştur. Ölçeğin toplam puanı için Cronbach alfa katsayısı .81 olarak hesaplanmıştır (Bugay ve Demir, 2010, s. 1927-1931).

\section{İşlem}

Araştırmada kullanılan veri toplama araçları Üniversite etik kurul onayından sonra 18 yaş üzeri yaş grubu gönüllü bireylere yazılı onamları alındıktan sonra araştırmacılar tarafindan yüz yüze uygulanmıştır. Uygulama ortalama 15 dakika sürmüştür.

\section{Verilerin Analizi}

Araştırmanın veri analiz bölümünde öncelikle kişisel bilgi formu sorularına verilen yanıtların frekans ve yüzdelik dağılımları hesaplanmıstır. Araştırmada kullanılan ölçeklerin her bir alt boyutunun toplam ve maddelerinin aritmetik ortalama, standart sapmaları ve maksimum-minimum değerleri belirlenmiştir. Ayrıca her bir ölçek puan dağılımlarının normalliğini saptamak üzere Kolmogov-Smirnov testi yapılmıştır. Yapılan işlemler sonucunda H0 hipotezleri kabul edildiği için, araştırma kapsamında parametrik istatistiksel tekniklerin kullanılmasına karar verilmiştir. Ölçek alt boyut ortalamaları arasındaki farklılıkların sınanması için "ki-kare testi”, " ilişkisiz grup "t" testi ve Tek yönlü varyans analizi (ANOVA) işlemi yapılmıştır. ANOVA'da istatistiksel açıdan farklılık bulunduğu durumlarda bu kümülatif farklılığın hangi ikili gruplar arasından kaynaklandığını belirlemek için post-hoc tekniklerden Scheffe veya Tamhane çoklu karşılaştırma testi gerçekleştirilmiştir.

\section{Bulgular}

Araştırma sorularına yanıt aranmadan önce kullanılan bütün ölçeklerin ortalama, standart sapma ve dağılım değerleri Tablo 1'de sunulmuştur.

\section{Gerçek Doğum Sırası Aynı Zamanda Psikolojik Doğum Sırası mı?}

Araştırmada ilk olarak Çalışma Grubunun Gerçek Doğum Sırası ile Psikolojik Doğum Sırası Arasında Hesaplanan Kontinensi Korelasyon Katsayısı .193'dir. Elde edilen bu sonuç istatistiksel açıdan anlamlı değildir. Bireylerin gerçek doğum sırasıyla psikolojik doğum sırası arasında anlamlı ilişki yoktur. 
Tablo 1. Calısma Grubuna Uygulanan Tüm Ölçek Puanlarmm Aritmetik Ortalamaları, Standart Sapmaları ve Puan Dağılım Değerleri

\begin{tabular}{llccccc}
\hline \multicolumn{1}{c}{ Ölçekler } & \multicolumn{1}{c}{$\begin{array}{c}\text { Alt } \\
\text { Boyutlar }\end{array}$} & Art.Ort & ss & $\begin{array}{c}\text { Maksimum } \\
\text { Minimum Değer }\end{array}$ & $\begin{array}{c}\text { Komogrov } \\
\text { Smirov }\end{array}$ & p \\
& Büyük Çocuk & 5.6551 & 3.16819 & $0-11$ & 1.096 & .181 \\
& Ortanca Çocuk & 1.5236 & 2.19255 & $0-10$ & .729 & .663 \\
Psikolojik Doğum Sırası & Küçük Çocuk & 3.2184 & 1.74121 & $0-7$ & .843 & .476 \\
& Tek Çocuk & 1.8362 & 1.81973 & $0-9$ & .968 & .451 \\
\hline Öz Anlayış Ölçeği & Toplam & 78.9950 & 15.85553 & $24-118$ & .959 & .317 \\
\hline Genel Aidiyet Ölçeği & Toplam & 69.7295 & 13.15441 & $23-84$ & .890 & .387 \\
\hline Heartland Affetme Ölçeği & Toplam & 81.2059 & 16.18528 & $19-118$ & .729 & .663 \\
\hline
\end{tabular}

\section{Gerçek Doğum Sırası ve Psikolojik Doğum Sırası ile Problem Alanları}

Bireylerin problem yaşadığı alanlar gerçek doğum sırasına göre incelendiğinde; akademik $\left(\mathrm{X}^{2}=2.07\right.$, $\mathrm{p}=.56)$, aile $\left(\mathrm{X}^{2}=.51, \mathrm{p}=.92\right)$, arkadaş $\left(\mathrm{X}^{2}=2.79, \mathrm{p}=.42\right)$, ekonomik $\left(\mathrm{X}^{2}=1.91, \mathrm{p}=.59\right)$, romantik ilişki $\left(\mathrm{X}^{2}=.95, \mathrm{p}=.81\right)$, sigara/alkol/madde $\left(\mathrm{X}^{2}=.87, \mathrm{p}=.83\right)$, kişilik $\left(\mathrm{X}^{2}=1.65, \mathrm{p}=.65\right)$, cinsellik $\left(\mathrm{X}^{2}=5.35\right.$, $\mathrm{p}=.15)$ ve uyum $\left(\mathrm{X}^{2}=5.29, \mathrm{p}=.15\right)$ problem alanlarının gerçek doğum sırasına göre farklılaşmadığı; sadece duygusal $\left(\mathrm{X}^{2}=7.94, \mathrm{p}<.05\right)$ problem alanlarının gerçek doğum sırasına göre anlamlı düzeyde farklılaştı̆̆ görülmektedir. Buna göre ortanca çocukların \%32.9’u ve küçük çocukların \%35.1'i duygusal sorunlar yaşadıklarını belirtirken, tek çocukların \%50'si ve büyük çocukların \%47.8'I duygusal sorun yaşadıklarını ifade etmişlerdir.

Tablo 2. Çalışma Grubunun Gerçek Doğum Sirası ile Psikolojik Doğum Sirası Arasında Hesaplanan Kontinensi Korelasyon Katsayısı

\begin{tabular}{|c|c|c|c|c|c|c|}
\hline \multirow{2}{*}{$\begin{array}{l}\text { Bağımsız } \\
\text { Değişken }\end{array}$} & \multirow[b]{2}{*}{ Katagori } & \multirow[b]{2}{*}{ Büyük Çocuk } & \multicolumn{3}{|c|}{ Psikolojik Doğum Sırası } & \multirow[b]{2}{*}{ Toplam } \\
\hline & & & Ortanca Çocuk & Küçük Çocuk & Tek Çocuk & \\
\hline Gerçek & Büyük Çocuk & 45 & 30 & 37 & 24 & 136 \\
\hline \multirow[t]{9}{*}{ Doğum Siras1 } & & $33.1 \%$ & $22.1 \%$ & $27.2 \%$ & $17.6 \%$ & $100.0 \%$ \\
\hline & Ortanca Çocuk & 31 & 25 & 13 & 16 & 85 \\
\hline & & $36.5 \%$ & $29.4 \%$ & $15.3 \%$ & $18.8 \%$ & $100.0 \%$ \\
\hline & Küçük Çocuk & 39 & 28 & 54 & 33 & 154 \\
\hline & & $25.3 \%$ & $18.2 \%$ & $35.1 \%$ & $21.4 \%$ & $100.0 \%$ \\
\hline & Tek Çocuk & 7 & 5 & 8 & 8 & 28 \\
\hline & & $25.0 \%$ & $17.9 \%$ & $28.6 \%$ & $28.6 \%$ & $100.0 \%$ \\
\hline & Toplam & 122 & 88 & 112 & 81 & 403 \\
\hline & & $30.3 \%$ & $21.8 \%$ & $27.8 \%$ & $20.1 \%$ & $100.0 \%$ \\
\hline
\end{tabular}

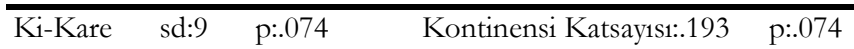

Bireylerin problem yaşadığı alanlar psikolojik doğum sırasına göre incelendiğinde akademik problem yaşayan bireylerin psikolojik doğum sırası ortanca çocuk puan ortalamaları (2.00), yaşamayanlardan (1.41) $(\mathrm{t}=2.18 ; \mathrm{p}<.05)$ ve tek çocuk puan ortalamaları $(2.40)$, yaşamayanlardan $(1.70)(\mathrm{t}=3.129 ; \mathrm{p}<.01)$ anlamlı düzeyde daha yüksek düzeydedir. Aile problemleri yaşayan bireylerin psikolojik doğum sırası büyük çocuk puan ortalamaları (6.12), yaşamayanlardan (5.42) $(\mathrm{t}=2.093 ; \mathrm{p}<.05)$; ortanca çocuk puan ortalamaları (2.41), yaşamayanlardan $(1.07)(\mathrm{t}=6.042 ; \mathrm{p}<.001)$ ve tek çocuk puan ortalamaları $(2.18)$, yaşamayanlardan $(1.66)$ $(\mathrm{t}=2.695 ; \mathrm{p}<.01)$ anlamlı düzeyde daha yüksektir. Bununla birlikte aile problemleri yaşayan bireylerin psikolojik doğum sırası küçük çocuk puan ortalamaları (2.93), yaşamayanlardan (3.37) anlamlı düzeyde daha düşüktür $(\mathrm{t}=-2.407) ; \mathrm{p}<.01)$.

Arkadaş problemleri yaşayan bireylerin psikolojik doğum sırası ortanca çocuk puan ortalamaları (2.29), yaşamayanlardan (1.39) anlamlı düzeyde daha yüksektir ( $\mathrm{t}=2.916 ; \mathrm{p}<.01)$. Ekonomik problem yaşayan bireylerin psikolojik doğum sırası büyük çocuk puan ortalamaları (5.26), yaşamayanlardan (5.93) anlamlı düzeyde daha düşüktür $(\mathrm{t}=-2.109 ; \mathrm{p}<.05)$. Romantik ilişki problemleri yaşayan bireylerin psikolojik doğum sırası ortanca çocuk puan ortalamaları (1.97), yaşamayanlardan (1.31) $(\mathrm{t}=2.822 ; \mathrm{p}<.01)$ ve tek çocuk puan ortalamaları (2.20), yaşamayanlardan (1.66) anlamlı düzeyde daha yüksektir ( $\mathrm{t}=2.788 ; \mathrm{p}<.01)$. Duygusal problemler yaşayan bireylerin psikolojik doğum sırası büyük çocuk puan ortalamaları (6.17), yaşamayanlardan (5.31) $(\mathrm{t}=2.984 ; \mathrm{p}<.01)$ ve ortanca çocuk puan ortalamaları (1.92), yaşamayanlardan (1.26) anlamlı düzeyde daha yüksektir ( $\mathrm{t}=2.984 ; \mathrm{p}<.01)$. 
Sigara/alkol/madde problemleri yaşayan bireylerin psikolojik doğum sırası büyük çocuk puan ortalamaları (4.55), yaşamayanlardan (5.83), $(\mathrm{t}=-2.819 ; \mathrm{p}<.01)$; küçük çocuk puan ortalamaları (2.76), yaşamayanlardan (3.29) anlamlı düzeyde daha düşüktür $(\mathrm{t}=-2.093 ; \mathrm{p}<.05)$. Bununla birlikte Sigara/alkol/madde problemleri yaşayan bireylerin psikolojik doğum sırası tek çocuk puan ortalamaları (2.44), yaşamayanlardan (1.74) anlamlı düzeyde daha yüksek bulunmuştur ( $\mathrm{t}=2.652 ; \mathrm{p}<.01)$. Kişilik problemleri yaşayan bireylerin psikolojik doğum sirası ortanca çocuk puan ortalamaları (2.88), yaşamayanlardan $(1.29)(\mathrm{t}=5.385 ; \mathrm{p}<.001)$ ve tek çocuk puan ortalamaları (2.32), yaşamayanlardan $(1.75)$ anlamlı düzeyde daha yüksek bulunmuştur $(\mathrm{t}=2.228 ; \mathrm{p}<.05)$. Ayrıca; cinsel problem yaşayan bireylerin psikolojik doğum sırası ortanca çocuk puan ortalamaları (2.58), yaşamayanlardan (1.46), $(\mathrm{t}=2.457 ; \mathrm{p}<.05)$ ve tek çocuk puan ortalamaları (2.71), yaşamayanlardan (1.78) anlamlı düzeyde daha yüksek bulunmuştur $(\mathrm{t}=2.436 ; \mathrm{p}<.05)$. Son olarak uyum sorunu yaşayan bireylerin psikolojik doğum sırası ortanca çocuk puan ortalamalar1 (2.51), yaşamayanlardan (1.39) anlamlı düzeyde daha yüksek bulunmuştur ( $t=3.325 ; \mathrm{p}<.001)$.

\section{Gerçek ve Psikolojik Doğum Sırası ile Öz-anlayış Arasındaki İlişki}

Gerçek doğum sırası tek çocuk olanların özanlayış toplam puan ortalaması 80.89 ile birinci sıradadır. Bunu 80.78 ortalama ile ortanca çocuklar izlemiştir. En düşük ortalama değeri ise büyük çocuklardan elde edilmiştir. Tablo 1'de görüldüğü üzere Gerçek doğum sırasına göre grupların öz anlayış puan ortalamaları için yapılan tek yönlü varyans analizinde (ANOVA) istatistiksel açıdan anlamlı bir sonuç bulunamamıştır $(\mathrm{F}=1.631 ; \mathrm{p}>.05)$.

Tablo 3. Calısma Grubunun Gerçek Doğum Sirasma Göre Öz. Anlayzş Toplam Puan Ortalamalarn İçin Yapılan Tek Yönlü Varyans Analizi (ANOV A) 'F”' Testi Sonuclar

\begin{tabular}{lcccccc}
\hline Gerçek & N & Art.Ort & ss & F & sd & p \\
Doğum Sırası & 136 & 76.6250 & 15.99488 & 1.631 & $3-399$ & .182 \\
\hline Büyük Çocuk & 85 & 80.7765 & 16.06710 & & & \\
Ortanca Çocuk & 154 & 79.7597 & 15.75094 & & & \\
Küçük Çocuk & 28 & 80.8929 & 14.47434 & & \\
Tek Çocuk & 403 & 78.9950 & 15.85553 & & \\
Toplam & & & & & & \\
${ }^{*} \mathrm{p}<.05{ }^{* * *} \mathrm{p}<.01$ & ${ }^{* * *} \mathrm{p}<.001$ & &
\end{tabular}

Tablo 4'de görüldüğü üzere; Psikolojik doğum sırası küçük çocuk olanların öz anlayış toplam puan ortalaması 83.04 ile birinci sıradadır. Bunu 81.27 ortalama ile büyük çocuklar izlemiştir. En düşük ortalama değeri ise Psikolojik doğum sırası ortanca olan çocuklardan elde edilmiştir. Psikolojik doğum sırasına göre grupların öz anlayış puan ortalamaları için yapılan tek yönlü varyans analizinde (ANOVA) istatistiksel açıdan anlamlı bir sonuç elde edilmiştir ( $\mathrm{F}=8.251 ; \mathrm{p}<.001)$. Psikolojik doğum sırası farklı olan çocukların Öz anlayış toplam puan ortalamaları birbirinden farklılaşmışıtır. Yapılan Scheffe Testi Sonuçlarına göre Psikolojik doğum sırasına göre Büyük çocuk olanların öz anlayış puan ortalamaları ortanca çocuklardan anlamlı derecede daha yüksektir $(\mathrm{p}<.01)$. Psikolojik doğum sırasına göre ortanca çocuk olanların öz anlayış puan ortalamaları, küçük çocuklardan anlamlı derecede daha düşüktür $(\mathrm{p}<.001)$. Psikolojik doğum sırasına göre küçük çocuk olanların öz anlayış puan ortalamaları, tek çocuklardan anlamlı derecede daha yüksektir $(\mathrm{p}<.05)$.

Tablo 4. Çalssma Grubunun Psikolojik Doğum Sırasina Göre Öz. Anlayıs Toplam Puan Ortalamalar İçin Yapılan Tek Yönlü Varyans Analizi (ANOVA) "F”' Testi Sonuclar

\begin{tabular}{lcccccc}
\hline Psikolojik & N & Art.Ort & ss & F & sd & p \\
Doğum Sırası & 122 & 81.2705 & 15.49835 & 8.251 & $3-399$ & $.000^{* * *}$ \\
\hline Büyük Çocuk & 88 & 73.4205 & 14.82365 & & & \\
Ortanca Çocuk & 112 & 83.0357 & 15.04643 & & & \\
Küçük Çocuk & 81 & 76.0370 & 16.52532 & & \\
Tek Çocuk & 403 & 78.9950 & 15.85553 & & \\
Toplam & & & & &
\end{tabular}




\section{Gerçek ve Psikolojik Doğum Sırası ile Affetme Arasındaki İlişki}

Tablo 5. Çalışma Grubunun Gerçek Doğum Sırasına Göre Heartland Affetme Ölçĕgi Toplam Puan Ortalamalar İcin Yapılan Tek Yönlü V aryans Analizi (ANOV A) "F"' Testi Sonuclar

\begin{tabular}{lcccccc}
\hline Gerçek & N & Art.Ort & ss & F & sd & p \\
Doğum Sırasi & 132 & 80.0682 & 16.03441 & 2.847 & $3-393$ & $.037^{*}$ \\
\hline Büyük Çocuk & 85 & 85.3765 & 16.46495 & & & \\
Ortanca Çocuk & 152 & 82.0461 & 15.46769 & & & \\
Küçük Çocuk & 28 & 87.2500 & 15.15262 & & & \\
Tek Çocuk & 397 & 82.4685 & 15.96436 & & & \\
Toplam & & & & & &
\end{tabular}

Tablo 5’te görüldüğü gibi; Gerçek doğum sırası tek çocuk olanların Heartland Affetme Ölçeği toplam puan ortalaması 87.25 ile birinci sıradadır. Bunu 85.38 ortalama ile ortanca çocuklar izlemiştir. En düşük ortalama değeri ise büyük çocuklardan elde edilmiştir (80.07). Gerçek doğum sırasına göre grupların Affetme Ölçeği Toplam puan ortalamaları için yapılan tek yönlü varyans analizinde (ANOVA) istatistiksel açıdan anlamlı bir sonuç elde edilmiştir $(\mathrm{F}=2.847 ; \mathrm{p}<.05)$. Gerçek doğum sırası farklı olan çocukların Affetme Ölçeği toplam puan ortalamaları birbirinden farklılık göstermiştir. Bu farklılık kümülatif bir farklılıktır. Bu farklılığın hangi ikili gruplar arasından kaynaklandığını belirlemek üzere post-hoc tekniklerden Scheffe testi yapılmıştır. Çalışma grubunun Gerçek Doğum Sırasına göre Heartland Affetme toplam puan ortalamaları İçin yapılan Scheffe testi sonuçlarında hiçbir anlamlı sonuç elde edilememiştir.

Tablo 6. Calışma Grubunun Psikolojik Doğum Sirasına Göre Heartland Affetme Ölçeği Toplam Puan Ortalamalar İcin Yapılan Tek Yönlü Varyans Analizi (ANOV A) 'F”' Testi Sonuclar

\begin{tabular}{lcccccc}
\hline Psikolojik & N & Art.Ort & ss & F & sd & p \\
Doğum Sırası & 119 & 85.0756 & 15.24053 & 3.657 & $3-393$ & $.013^{*}$ \\
\hline Büyük Çocuk & 86 & 80.6860 & 14.85876 & & & \\
Ortanca Çocuk & 111 & 84.0631 & 16.52176 & & & \\
Küçük Çocuk & 81 & 78.3457 & 16.57646 & & \\
Tek Çocuk & 397 & 82.4685 & 15.96436 & & \\
Toplam & & & & & & \\
\hline${ }^{*}<.05{ }^{* *} \mathrm{p}<.01$ & $* * * \mathrm{p}<.001$ & &
\end{tabular}

Tablo 6'te görüldüğü üzere; Psikolojik doğum sırası büyük çocuk olanların Heartland Affetme Ölçeği toplam puan ortalaması 85.08 ile birinci sıradadır. Bunu 84.06 ortalama ile küçük çocuklar izlemiştir. En düşük ortalama değeri ise tek çocuklardan elde edilmiştir (78.35). Psikolojik doğum sırasına göre grupların Heartland Affetme Ölçeği Toplam puan ortalamaları için yapılan tek yönlü varyans analizinde (ANOVA) istatistiksel açıdan anlamlı bir sonuç elde edilmiştir ( $F=3.657 ; \mathrm{p}<.05)$. Psikolojik doğum sırası farklı olan çocukların Heartland Affetme Ölçeği toplam puan ortalamaları birbirinden farklılık göstermiştir. Bu farklılık kümülatif bir farklılıktır. Bu farklılığın hangi ikili gruplar arasından kaynaklandığını belirlemek üzere post-hoc tekniklerden Scheffe testi yapılmıştır. Yapılan Scheffe testi sonucuna göre Psikolojik Doğum Sirasına göre Büyük Çocukların Heartland Affetme Ölçeği Toplam Puan Ortalaması, Tek çocuklardan anlamlı derecede daha yüksek düzeydedir( $(\mathrm{p}<.05)$. Diğer ikili karşılaştırmalar arasında anlamlı farkliliklar bulunamamıştır.

\section{Gerçek ve Psikolojik Doğum Sırası ile Genel Aidiyet Arasındaki İlişki}

Tablo 7. Calısma Grubunun Gerçek Doğum Sirasina Göre Genel Aidiyet Ölçeği Toplam Puan Ortalamalar İçin Yapulan Tek Yönlï Varyans Analizi (ANOV A) 'F”' Testi Sonuclar

\begin{tabular}{|c|c|c|c|c|c|c|}
\hline $\begin{array}{l}\text { Gerçek } \\
\text { Doğum Sırası }\end{array}$ & $\mathbf{N}$ & Art.Ort & ss & $\mathbf{F}$ & sd & $\mathrm{p}$ \\
\hline Büyük Çocuk & 136 & 69.4338 & 13.54209 & .933 & $3-399$ & .425 \\
\hline Ortanca Çocuk & 85 & 68.6235 & 13.77452 & & & \\
\hline Küçük Çocuk & 154 & 69.9481 & 12.81839 & & & \\
\hline Tek Çocuk & 28 & 73.3214 & 10.95801 & & & \\
\hline Toplam & 403 & 69.7295 & 13.15441 & & & \\
\hline
\end{tabular}


Tablo 7’te görüldüğü üzere; Gerçek doğum sırası tek çocuk olanların Genel Aidiyet Ölçeği toplam puan ortalaması 73.32 ile birinci sıradadır. Bunu 69.95 ortalama ile küçük çocuklar izlemiştir. En düşük ortalama değeri ise ortanca çocuklardan elde edilmiştir (68.62). Gerçek doğum sırasına göre grupların Genel Aidiyet Ölçeği Toplam puan ortalamaları için yapılan tek yönlü varyans analizinde (ANOVA) istatistiksel açıdan anlamlı bir sonuç elde edilememiştir ( $\mathrm{F}=.933 ; \mathrm{p}>.05)$.

Tablo 8. Callşma Grubunun Psikolojik. Doğum Sirasına Göre Genel Aidiyet Ölçeği Toplam Puan Ortalamalar İ̧̇in Yapulan Tek Yönlü Varyans Analiži (ANOVA) "F” Testi Sonuçlar

\begin{tabular}{lcccccc}
\hline Psikolojik & N & Art.Ort & ss & F & sd & p \\
Doğum Sırasi & 122 & 73.3852 & 9.49941 & 30.730 & $3-399$ & $.000^{* * *}$ \\
\hline Büyük Çocuk & 88 & 61.3182 & 14.51083 & & & \\
Ortanca Çocuk & 112 & 75.4732 & 8.92507 & & \\
Küçük Çocuk & 81 & 65.4198 & 15.17635 & & \\
Tek Çocuk & 403 & 69.7295 & 13.15441 & & \\
Toplam & & & & &
\end{tabular}

Tablo 8'da görüldüğü gibi; Psikolojik doğum sırası küçük çocuk olanların Genel Aidiyet Ölçeği toplam puan ortalamas1 75.47 ile birinci sıradadır. Bunu 73.39 ortalama ile büyük çocuklar izlemiştir. En düşük ortalama değeri ise ortanca çocuklardan elde edilmiştir (61.32). Psikolojik doğum sırasına göre grupların Genel Aidiyet Ölçeği Toplam puan ortalamaları için yapılan tek yönlü varyans analizinde (ANOVA) istatistiksel açıdan anlamlı bir sonuç elde edilmiştir ( $\mathrm{F}=30.730 ; \mathrm{p}<.001)$. Psikolojik doğum sırası farklı olan çocukların Genel Aidiyet Ölçeği toplam puan ortalamaları birbirinden farklı düzeydedir. Bu farklılık kümülatif bir farklılıktır. Bu farklılığın hangi ikili gruplar arasından kaynaklandığını belirlemek üzere post-hoc tekniklerden Tamhane testi yapılmışır. Psikolojik Doğum Sırasına göre büyük çocukların Genel Aidiyet Ölçeği Toplam Puan Ortalaması, Ortanca $(\mathrm{p}<.001)$ ve tek $(\mathrm{p}<.001)$ çocuklardan anlamlı derecede daha yüksek düzeydedir. Psikolojik Doğum Sırasına göre küçük çocukların puan ortalaması, ortanca $(\mathrm{p}<.001)$ ve tek çocuklardan anlamlı düzeyde daha yüksektir $(\mathrm{p}<.001)$. Diğer ikili karşılaştırmalar arasında anlamlı farklılıklar bulunamamıstır.

\section{Tartışma}

$\mathrm{Bu}$ araştırmada öncelikle bireylerin gerçek doğum sırasının psikolojik doğum sırası ile ilişkileri belirlenmeye çalışılmış, bir diğer deyişle gerçekte aile sisteminde var olan doğum sırasını psikolojik açıldan da koruyup korumadığ incelenmiştir. Araştırma sonucuna göre gerçek doğum sırası ile psikolojik doğum sırası arasında anlamlı bir ilişki bulunmamıştır.

Alanyazını incelendiğinde bireylerin psikolojik doğum sıralarının gerçek doğum sıralarından farklılaşabileceği belirtilmektedir (Stewart ve Campbell, 1998, s. 42-60). Gerçek doğum sırası ve psikolojik doğum sırasının aynı şey olmadığını gösteren araştırmalar bulunmaktadır (Campbell vd, 1991, s. 380-391; Kalkan ve Koç, 2007, s. 45-59). Bireyler gerçek doğum sırası dışında, aile içinde kendilerini konumlandırdıkları bir psikolojik doğum sırası pozisyonu geliştirmektedirler (Campbell vd, 1991, s. 380391). Bireylerin farklı doğum sırası pozisyonuna ait kişilik özelliklerine sahip olabilecekleri ve gerçek doğum sırası pozisyonunu etkileyebilecek aile ortamı, kardeşlerin cinsiyeti, kardeşlerin yaş farkı, aile yapısı gibi pek çok etmenin varlı̆̆ından bahsedilmektedir (Leman, 2011).

Lohman vd., (1985, s. 313-327) gerçek doğum sırası ve psikolojik doğum sırası konumları arasında farklılık olduğunu belirtmektedir. Araştırma bulguları arasında gerçek doğum sırası ile psikolojik doğum sırası konumu arasında büyük çocuk pozisyonunda yüksek oranda benzerlik bulunduğu yer almaktadır ve bu bulgu bizim araştırma sonucumuzu destekler niteliktedir. Bu araştırmada bireylerin gerçek doğum sırası ile tüm psikolojik doğum sırası konumları arasında anlamlı bir fark bulunamaması, bireylerin gerçek doğum sırasının belirli bir psikolojik doğum sırası pozisyonuyla eşleşemeyecek kadar çok etmenin etkisi altında şekilleniyor oluşuyla açıklanabilir. Büyük çocuk ve küçük çocuk gerçek doğum sırası pozisyonunun diğer doğum sırası pozisyonlarından farklı olarak psikolojik doğum sırası puan ortalamaları ile anlamlı farka sahip olması, genel olarak aile sistemi içinde ilk doğan çocuğa yüklenen anlam ve büyütülme şekli ile en küçük çocuğun aile içinde kendine yer açma şeklinin diğer doğum sırası pozisyonlarına oranla istikrarlı tutumlarla şekillenmesinden ve gerçek doğum sırası konumuna benzerliğinden kaynaklanıyor olabileceği düşünülmektedir. Ancak bu yorum için daha fazla araştırmaya ihtiyaç duyulmaktadır. 


\section{Doğum Sirası ve Problem Alanları}

Araştırmada incelenen bir diğer soru ise, bireylerin problem yaşadıkları alanların gerçek ve psikolojik doğum sırasına göre farklılaşıp farklılaşmadığıdır. Problem alanları gerçek ve psikolojik doğum sırasına göre farklılık gösterip göstermediği incelendiğinde; bireylerin akademik, aile, arkadaşlık, ekonomik, sigara/alkol/madde kullanımı, kişilik, cinsellik ve uyum sorun alanlarında gerçek doğum sırasına göre farklılaşmadığı ancak büyük ve tek çocukların daha fazla duygusal sorun yaşadığı bulunmuştur.

Psikolojik doğum sırası ile problem alanları arasındaki ilişkiye bakıldığında, psikolojik doğum sırası ortanca ve tek çocukların daha fazla akademik problem yaşadığı bulunmuştur. Akademik başarısı yüksek ve buna bağlı olarak akademik problemlerle en az uğraşan çocuklar genellikle büyük çocuklardır (Eckstein vd., 2010, s. 408-434). Büyük çocuklardan sonra en yüksek akademik başarı tek çocuklarda görülmektedir (Eckstein vd., 2010, s. 408-434). Ama başarıya en çok ihtiyaç duyan bireyler de özellikle tek çocuklar arasında daha fazla temsil edilmektedir (Eckstein, 2000, s. 481-494). Buna ek olarak tek çocuklar başarı motivasyonları oldukça yüksek bireylerdir (Fablo ve Polit, 1986, s. 176-189). Ailede tek çocuk olmak ebeveynlerin tüm başarı beklentilerini üstlenmek zorunda bırakması nedeniyle, yıpratıcı olabilmektedir. Hissedilen yüksek başarı hedefleri tek çocuk üzerinde baskı yaratıp problem yaşamasına neden olabileceği düşünülmektedir. $\mathrm{Bu}$ açıdan büyük çocuklar başka kardeşlerinin başarı veya başarısızlı̆̆ ile kendisine yönelik akademik baskıyı motivasyona dönüştürebilirken, tek çocuğun başarılı olmaktan başka çaresi yoktur. Geniş bir örneklem üzerinde gerçekleştirilen bir araştırma bulgusu yine önce doğan bireylerin sonra doğanlara göre daha yüksek akademik ortalama ve başarı eğilimi ile ilişkili olduğunu göstermektedir (Fergusson, Horwood ve Boden, 2006, s. 122-139). Ortanca çocuklar ise ailede ilk çocuk ile rekabet içinde oldukların hissedebilirler ve bu rekabet ortanca çocukları akademik yönden başarılı olan büyük çocukla kendini kıyaslamasına neden olabileceği düşünülmektedir. Hatta ortanca çocuklar büyük çocuğun tam tersi özelliklere sahip olmasıyla karakterize olmuştur (Leman, 2011). Özellikle ortanca çocukların ilk çocuğun denemediği alanda başarılı olmaya eğilimli olduğu vurgulanmaktadır (Leman, 1997). Eckstein vd. (2010)'da gerçekleştirdiği meta analiz çalışmasında ortanca çocukların daha çok takım oyunlarında yüksek başarıya sahip olduklarını göstermektedir (Eckstein vd., 2010, s. 408-434). Bu açıdan bakıldığında araştırma bulgular1 literatür ile paralellik göstermektedir.

Öte yandan ailevi problemleri psikolojik doğum sırası büyük, ortanca ve tek çocuk olan bireyler, psikolojik doğum sırası küçük çocuk olan bireylerden daha fazla yaşamaktadır. Önceki çalışmalar (Salmon ve Daly, 1998, s. 299-312) cinsiyet ve gerçek doğum sırasının ailevi duyguların güçlü belirleyicileri olduğunu göstermektedir. Aile atmosferi ve desteği çocukların geleceği algılama şekillerini ve duygusal yönden doyum hissetmelerini etkileyen önemli bir unsurdur (Trommsdorf, 1983, s. 381-406). Bu açıdan bireylerin ailevi problemleri algılama şekilleri yetişkinlik ilişkilerine de yansıyacak oluşuyla ayrı bir önem taşımaktadır. Araştırma bulguları aile problem alanında en fazla sorun yaşan bireylerin psikolojik doğum sırası büyük, ortanca ve tek çocuk olan bireyler olduğunu göstermektedir. Büyük çocuklar ailede stresi tamponlama ve daha küçük kardeşlere destek sağlama görevi görmektedir (Hollifield ve Cogner, 2015, s. 143-153). Ayrıca ilk kardeşin doğumu ile birlikte abi ya da abla rolünü de üstlenmeye başlayan büyük çocuklar, kardeşlerini korumak ve kimi zaman ebeveyne karşı savunan taraf olmak durumunda kalmaktadır. Ortanca çocuklar, büyük çocuklardan veya küçük çocuklardan daha az aile yönelimli olma eğilimindedir (Salmon, 2003, s. 73-88). Yapılan bir araştırma ortanca çocukların aile desteğinden daha çok arkadaş desteği aldığını ve aileye yönelik tutumlarının arkadaşlarına oranla daha olumsuz olduğunu göstermektedir (Salmon, 2003, s. 73-88). Ayrıca annelerin favori çocuklarının hangisi olduğunu belirlemek üzere yapılan başka bir araştırmada ortanca çocuklar anneler tarafından anlamlı ölçüde düşük oranda favori gösterilmiştir (Suitor ve Pillemer, 2007, s. 32-55). Tek çocuklar genelde ailede ilginin merkezindedir ve aşır1 dikkate maruz kalmaktadır. Bazı tek çocuklar ebeveynin dikkat ve öğütlerini baskı gibi hissetmektedir (Adler, 2018). Ayrıca tek çocuklar aile içi çatışmalarda tek başlarına kalmaktadır. Paylaşabilecekleri bir kardeşleri yoktur, ya da davranışlarını izleyip örnek alabilecekleri bir abisi/ablası da yoktur. Doğrudan aile ile yaşanan sorunların muhattabı konumuda yer almaktadırlar. Küçük çocuklar ise ailenin en son katılan ve sevimli bireyleridir. Genellikle küçük çocuklar aile içinde istediklerini elde etmek için cazibe, ikna, şikayet gibi davranışları sıkça kullanmaktadırlar (Gfreorer vd., 2003, s. 30-41; Stewart, Stewart ve Campbell, 2001, s. 363-387). Ailenin küçüğü konumunda oluşları çoğu zaman aile problemlerini en son duyan bireyler olmalarına neden olmaktadır (Leman, 2011 ). Kendisinden önce gelen kardeşlerinin hatalarından ders alarak, aile içinde daha az sorun yaşaması muhtemel bireyler olarak büyümektedirler (Adler, 2018). Bu açıdan bakıldığında araştırma bulguları literatür ile paralellik göstermektedir. 
Arkadaşlık problem alanı açısından değerlendirildiğinde; psikolojik doğum sırası ortanca çocuk olan bireylerin diğer psikolojik doğum sıralarına göre daha fazla problem yaşadıkları bulunmuştur. Ortanca çocuklar oldukça sosyal bireylerdir. Arkadaş çevreleri geniştir (Leman, 1997). Aynı zamanda büyük doğan çocuklara oranla sosyal ilgiyi geliştirme konusunda daha yetenekli görülmektedirler (Feist ve Feist, 2006). Salmon ve Daly (1998, s. 299-312) yapmış oldukları bir araştırmada, ortanca çocukların, aile ilişkilerini, ailevi duygularını ve flört /arkadaşlık yönelimlerini incelemiştir ve araştırma bulguları ortanca çocukların arkadaşlık ilişkisine yönelik aileden daha olumlu bir tutuma sahip olduklarını göstermektedir. Aynı zamanda bu araştırma bulguları ortanca çocukların, arkadaşlık ilişkisini aile ilişskisinden daha fazla sosyal destek aracı olarak algıladıkları sonucunu ortaya koymaktadır. Yapılan bir diğer araştırmada bireylerin psikolojik doğum sırası ile bireylerin stresle başa çıkma stratejileri arasındaki ilişki incelenmiştir. Araştırma bulguları, ortanca çocukların aile desteği, arkadaş kabulü ve sosyal güven alt boyut puanlarının en düşük ortalamaya sahip olduğunu göstermektedir (Kalkan ve Koç, 2007, s. 45-59; Pilkington vd., 1997, s. 42-57). Ortanca çocuklar çatışmalardan kaçınmaya çalışan, uzlaşmacı kişilik özelliklerine sahip bireyler olmalarının yanı sıra oldukça bağımsız kişilerdir. Arkadaşlarına son derece sadık olan ortancalar için bu arkadaşlık ilişkileri ve arkadaşlıkların sürdürülmesi önemlidir. Aile içinde ne olursa olsun ortanca konumlarından dolayı biraz dışlanmış hissettikleri için, arkadaş ortamında kalıcı ve sağlam ilişki arayışı içinde olmayı önemsedikleri düşünülmektedir (Leman, 1997). Bu açlardan arkadaşlık yönünden daha hassas ve kolay incinebilir yapıları nedeniyle psikolojik doğum sırası ortanca çocuk konumunda olan bireylerin diğer doğum sırası pozisyonlarına göre daha fazla problem yaşadıklarını belirttikleri düşünülmektedir.

Araştırma sonuçlarına göre, psikolojik doğum sırası büyük çocuk olan bireyler daha az ekonomik problem yaşamaktadır. Alanyazını, büyük çocukların mesleki prestij ve kariyer ilgileri açısından sonra doğanlardan daha iyi konumlarda çalışmaları muhtemel bireyler olduklarını ve gelirlerinin sonra doğan çocuklardan daha yüksek olduğunu göstermektedir (Davis, 1997, s. 205-230; Fergusson vd., 2006, s. 122139; Herara vd., 2003; White vd., 1997, s. 89-104). Aileden aldıklar1 eğitim avantajını (Eckstein vd., 2010, s. 408-434; Sulloway 1997), mesleki hayatlarında iyi pozisyonlara gelmek için kullanması muhtemel olan büyük çocuk doğum sırasına sahip bireyler için ekonomik sıkıntıların daha az yaşanması literatürle tutarlı bir bulgu olarak karşımıza çıkmaktadır.

Öte yandan romantik ilişki alanında, psikolojik doğum sırası ortanca ve tek çocuk olan bireyler daha fazla problem yaşamaktadır. Gerçek doğum sırası çalışmalarına iliş̧kin yapılmış meta analiz sonuçlarına göre Ortanca çocuklar romantik ilişkilerde partnerlerine sadık olma eğilimleri en fazla olan grubu temsil etmektedir (Eckstein vd., 2010, s. 408-434). Tek çocuk doğum sırasına ilişkin ise literatürde romantik ilişki alanına ait tutarlı bir bulgu yer almamaktadır. Ancak kardeş ilişkilerinde kıskançlık örüntüsüne bakıldığında, sonra doğanların ilk doğan çocuklara göre daha kıskanç olabileceği belirtilmektedir. Ayrıca aynı araştırma ilk doğan çocukların tek çocuklardan daha az kıskanç olduğu sonucu göstermektedir (Buunk, 1997, s. $997-$ 1006). Buna bağlı olarak kardeşler arasında edinilen kıskançlık duygularının yetişkinlik yaşamındaki romantik ilişkilere yansiyabileceği ve özellikle ortanca ve tek çocukların büyük ve küçük çocuk pozisyonuna göre daha fazla romantik ilişkilerde kıskançlık duygusuna sahip olabilecekleri belirtilmektedir. $\mathrm{Bu}$ da ortanca ve tek çocukların partnerlerinin ilgisini kaybetmeye tahammüllerinin daha az oluşuyla ve onların sevgilerini kaybetme korkusuyla açıklanmaktadır (McGurik ve Pettijohn II, 2008, s. 37-52) . Psikolojik doğum sırası ve irrasyonel ilişki inançları arasındaki ilişkiyi inceleyen bir başka araştırmaya göre tek çocuk doğum sırası ile irrasyonel ilişki inançları arasında ilişki bulunamazken, büyük çocukların irrasyonel ilişki inançları ile negatif yönde ilişkili olduğu, ortanca ve küçük çocuk doğum sırası ile irrasyonel ilişki inançlarının pozitif yönde anlamlı ilişkiye sahip olduğu sonucuna varılmaktadır (Kalkan, 2008, s. 455466). Ortanca çocuklar düşük öz saygı ve romantik ilişkilerde artan çaresizlik ve sevilmezlik inançlarıyla pozitif ilişsi göstermektedir. Romantik ilişkilerinde daha fazla problem yaşamalarının sebeplerinden biri ilişki doyumu düşük olmasına rağmen sürdürülen romantik ilişkilerin daha fazla ortanca doğum sırasinda görülmesi olabileceği düşünülmektedir. Ya da dış dünyada kabul edilme konusunda arayış içinde olan ortanca çocuklar için, kendi kurdukları ailelerinde partnerin ilgisini veya sevgisini kaybetmeye yönelik duydukları yoğun endişe, ve irrasyonel ilişki inançlarının fazlalığı nedeniyle ortaya çıkan çaresizlik hisleri olduğu yine düşünülebilir. $\mathrm{Bu}$ açlardan değerlendirildiğinde, ilerleyen dönemlerde romantik ilişki alanı ile ilgili özellikle psikolojik doğum sırasına yönelik kapsamlı araştırmaların yapılmasına ihtiyaç duyulmaktadır.

Duygusal problem alanındaki bulgulara bakıldığında, psikolojik doğum sırası büyük ve ortanca çocuk olan bireylerin puan ortalamaları diğer psikolojik doğum sırası puan ortalamalarına göre anlamlı ölçüde yüksek bulunmuştur. Büyük çocukların daha fazla duygusal problem yaşadığı bulgusu, bu problem alanının gerçek doğum sırasına ilişkin sonuçlarıyla da desteklenmiştir. Psikolojik doğum sırasına göre büyük 
çocuklar başkalarının bakım ve ihtiyaçlarıyla ilgilenen, endişeli yapıya sahip olan bireyler olarak görülmektedir (Feist ve Feist, 2006). Kardeşlerinin bakımı da dahil olmak üzere pek çok sorumluluk yüklenen büyük çocuklar, aynı zamanda kaygılı ve mükemmelliyetçi kişilik özellikleri barındıran, yüksek beklentili bireylerdir (Leman, 2011). Somatik ve bilişsel kayg1 belirtileri büyük çocuk konumundaki sporcularda, küçük çocuk konumunda doğanlardan anlamlı derecede yüksek bulunması yine yüksek başarı hedefleri ile ilişkilidir (Flowers ve Brown, 2002, s. 41-56). Ayrıca büyük çocuğun yetiştirilme şekli ve ailenin ilk çocuğu olmasından dolayı annenin kaygısını aldığını iddia eden çalışmalar mevcuttur (Adams, 1972, s.411-439; Fablo ve Polit, 1986, s. 176-189). Psikolojik doğum sırası ortanca çocuk olan bireyler ise çaresizlik ve sevilmeme inançlarılla ilişkili görülmektedir (Kalkan ve Koç, 2007, s. 45-59). Ayrıca ortanca çocuklar kabul mücadelesi verdikleri için zaman zaman engellenmiş hissedebilirler (Adler, 2018). Kardeşlerin arasında kendilerini sıkışmış hissederek, yeteri kadar ebeveyn doyumu almadıklarını düşünerek geleceğe yönelik umutsuzluk duygularını besleyebilecekleri düşünülmektedir (Leman, 1997). Tanımlaması ve anlaşılması zor olan bu doğum sırası pozisyonu için 'artık büyüdün kardeşin gibi yapma ve o kadar büyümedin abin/ablan gibi olamazsın' ikilemi yüzünden ortanca çocuk konumundaki bireylerin, duygusal yönden problem yaşamaları muhtemel görülmektedir ve araştırma sonuçlarımızla uyumlu olduğu düşünülmektedir.

Araştırmanın bir diğer bulgusuna göre Psikolojik doğum sırası tek çocuk olan bireyler diğer doğum sırası konumlarına göre sigara/alkol/madde kullanımına ilişkin problemleri daha fazla yaşamaktadırlar. En az problem yaşayan psikolojik doğum sırası konumu ise büyük çocuklara aittir. Bazı araştırmalarda madde kullanımı için büyük çocuk doğum sırasının koruyucu bir faktör olduğu (Horner vd., 1998, s. 19-37) ve son doğan çocukların ilk doğanlara oranla daha fazla alkol kullandıkları (Laird ve Shelton, 2006, s. 18-35) bulgulanmıştır. Ayrıca, kendisinden büyük bir kardeşe sahip olan bireylerin suç eğilimli davranışlar sergilemeleri (çalma gibi), ya da alkol madde kullanma ihtimalleri büyük çocuklardan fazla olduğu belirtilmektedir (Argys vd., 2006, s. 215-233). Ama özellikle tüm ailenin ilgisini üzerinde toplamıs olan tek çocuk, hissettiği baskıyla başa çıkmak için alkol madde kullanımına yöneliyor olabileceği düşünülmektedir. Uyumsuz başa çıkma stratejileriyle ilişkili olduğu belirtilen çaresiz yaklaşım ile pozitif ilişkili olduğu belirtilen tek çocuklar için (Kalkan ve Koç, 2007, s. 45-59), stresten uzaklaşmak için ve odaktan uzaklaşmak için alkol madde kullanımı tercih ediliyor olabilir (Laird ve Shelton, 2006, s. 18-35). Ancak bireylerin alkol madde kullanımına ilişkin etkili olabilecek pek çok faktör daha vardır ve bu açıdan tek başına psikolojik doğum sırası bunu açıklamak için yeterli olmamaktadır.

Diğer taraftan; Psikolojik doğum sırası ortanca ve tek çocuk olan bireylerin daha fazla kişilik problem yaşadığı bulgulanmıştır. Kendine güven, içe dönüklük, kimlik karmaşası gibi kişilik problemlerini psikolojik doğum sırası ortanca ve tek çocuk olan bireyler daha fazla yaşamaktadır. Adler tek çocuk doğum sırası konumunu 'genellikle işbirliği ve sosyal ilişki açısından yoksun kalan, bağımlı bireyler olurlar' şeklinde tanımlamaktadır (Feist ve Feist, 2006). Uzun yıllar yapılmış araştırmalar tek çocukları doğal bir kontrol grubu olarak ele almıştır ve pek çok olumsuz kişilik problemleriyle ilişkili olduğu ifade edilmektedir (Adams, 1972, s.411-439). Ancak yakın dönem araştırmaları gerçek doğum sırası incelemelerinde kişilik özelliklerini araştırmak üzere yapılandırılırken tek çocuk doğum sırasını manipüle ederek çalışma dışı birakmay1 tercih etmektedir (Damian ve Roberts, 2015, s. 14119-14120; Rohrer, Egloff ve Schmukle, 2015, s. 14224-14229). Küçük çocuk ve büyük çocuğun karması olan tek çocuk pozisyonunun belli bir kişilik özelliğiyle ölçülememesi ve karşılaştırma yapılabilecek bir kardeş ilişkisinin olmayışı nedeniyle dahil edilmediği düşünülmektedir. Ortanca çocuklar içinde benzer bir durum söz konusudur. Ortanca çocukların kendi kişiliklerine yönelik tutum ve algıları aile pozisyonuyla ve büyük kardeş ile küçük kardeşin konumlarıyla yakından iliş̧ilidir (Feist ve Feist, 2006). Yapılan bir meta analiz çalış̧ması en yüksek ait olamama hissine ortanca çocukların sahip olduklarını göstermektedir (Eckstein, 2000, s. 481-494). Özellikle düşük aidiyet duygusunun, bireylerde mutsuzluğa, düşük benlik saygıs1, yalnızlık ve depresyon gibi psikolojik işlevlerin kaybıyla ilişkili olduğunu gösteren çalışmalar mevcuttur (Andersen vd., 2000; Duru, 2015, s. 37-47; Hill, 2006, s. 210-216; Osterman, 2000, s. 323-367). Dişadönüklük ise yüksek aidiyet duygularıyla ilişkili bir kişilik özelliğidir (Malone vd., 2012, s. 311-316). Hem aile desteğini en az hisseden (Pilkington vd., 1997, s. 42-57) hem de aidiyet duygusu en az olan ortancalar için kişilik yönünden problem yaşamaları muhtemel gözükmektedir.

Cinsellik problem alanında, psikolojik doğum sırası ortanca ve tek çocuk olan bireylerin daha fazla problem yaşadığı bulunmuştur. Romantik problem alanı ile tutarlı bir sonuç bulunmuş olması, romantik ilişskideki problemlerin bireylerin cinsel hayatlarına da yansımasıyla ilgili olabileceğini düşündürtmektedir. Özellikle evlilik doyumu kadınlarda sosyal uyumla ve eşle kurulan cinsel yakınlıkla bağlantılıdır ve evlilik 
uyumunu etkilemektedir. Ayrıca kadınların sosyal yakınlık beklentileri ile cinsellik ve eğlence beklentileri evlilik doyumunun yüksek olmasıyla anlamlı bir ilişkiye sahiptir (Greff ve Malherbe, 2001, s. 247-257). Birbiri ile ilişkili olan bu iki alanda psikolojik doğum sırası tek ve ortanca çocuk olan bireylerin daha fazla problem yaşıyor olması alanyazını ile tutarlı bir sonuç olarak görünmektedir.

Uyum problem alanı açısından değerlendirildiğinde; yeni ortam, okul veya işe uyum gibi durumlarda psikolojik doğum sırası ortanca çocuk olan bireyler daha fazla problem yaşamaktadır. Aile hayatlarında önlerinde hep bir adım ileride olan büyük kardeşle yarış halinde olan ortanca çocuklar için (Adler, 2018) yeni bir ortama girmek, yeni bir iş hayatına başlamak gibi doğrudan performansla ilişkili durumlar stres yaratıyor olabileceği düşünülmektedir. Ortanca çocuk doğum sırası genellikle konumu itibariyle kabul edilmeye yönelik üstün bir çaba sergilemektedir (Adler, 2018; Leman, 1997). Bu yönden, kişilik olarak işbirlikçi ve uyumlu olan ortancalar için yeni başlangıçlarda kabul edilmeme düşünceleri problem yaratıyor olabilir. Bu sonuca varabilmek için yeni araştırmalara ihtiyaç duyulmaktadır.

\section{Gerçek ve Psikolojik Doğum Sırası ve Aidiyet}

$\mathrm{Bu}$ araştırmada ele alınan bir diğer kavram ise genel aidiyet duygusudur. Bireylerin aidiyet puanlarının gerçek doğum sırasına göre farklılaşmadığı ancak psikolojik doğum sırası büyük ve küçük çocuk olan bireylerin, ortanca ve tek çocuk olan bireylerden anlamlı derecede daha yüksek genel aidiyet puan ortalamasına sahip oldukları görülmektedir.

Ait olmak insanın evrensel bir özelliğidir ve temel bir insan ihtiyacıdır (Maslow, 1970). Aile bireylerin ait olma ihtiyacını karşılayan en küçük toplumsal birimdir. Yapılan bir araştırma ailenin, arkadaş ve okul aidiyetinden daha önemli bir aidiyet kaynağı olduğunu göstermektedir (Yıldırım, 1997, s. 217-231). Aidiyet ve sevilme ihtiyacı karşlanan bireyler öz güven ve saygınlık ihtiyacını karşılamak üzere gelişimlerine devam eder ve kendini gerçekleştirme noktasına doğru ilerleyebilirler (Feist ve Feist, 2006).

Öz güven ve saygınlığın oluşabilmesi için gerekli olan aidiyet ve sevilme ihtiyacı karşılandığı takdirde bireyler kendilerine saygı duymaya, güven hissetmeye, başkalarının da kendilerine saygı duyduklarına inanmaya başlayabilirler (Feist ve Feist, 2006). Bunun için bireylerin ait oldukları grubu kabullenmeleri ve kabul gördüklerine inanmaları gereklidir (Andersen vd., 2000). Bu açıdan sosyal yönden en çok kabul gören ve ilgi alan psikolojik doğum sırası pozisyonu olan küçük çocuklar için (Eckstein vd., 2010, s. 408434) aidiyet düzeyinin kabul alt boyutunda anlamlı derecede yüksek bulunması tutarlı bir sonuçtur.

Genel aidiyet duygusunu farklı yönlerden ölçerek açıklamaya çalışan kapsamlı bir araştırmaya göre bireylerin sahip olduğu dişadönüklük ve kabul edilebilirlik özelliklerinin fazla olması yüksek aidiyet duygusuyla ilişkili olduğu belirtilmektedir (Malone vd., 2012, s. 311-316). Bu sonuçlar araştırma bulgumuzla ve küçük çocukların dışadönüklük (Herara vd., 2003; Leman, 1997), sempatiklik (Ickes ve Turner, 1983, s. 210-222) ve kabul edilebilirlik (Eckstein vd., 2010, s. 408-434) özellikleriyle uyumludur. Yapılan bir başka araştırmada ortanca çocukların aile desteği, arkadaş kabulü ve sosyal güven alt boyutlarından diğer doğum sıralarına göre anlamlı derecede düşük puan aldığı görülmektedir. Aynı araştırmada en yüksek puanı alan psikolojik doğum sırası pozisyonu büyük çocuklara aittir (Kalkan ve Koç, 2007, s. 45-59; Pilkington vd., 1997, s. 42-57). Bir bireyin aidiyet alg1s1 dahil olduğu grup say1s1 veya duygusal ilişki sıklığ ile değerlendirilemez. Önemli olan bireyin aidiyet ihtiyacının karşılanmasıdır (Duru, 2015, s. 37-47).

$\mathrm{Bu}$ açıdan daha sosyal olan ve sosyal ilişkiler yönünden büyük çocuktan daha fazla arkadaş yönelimli ortanca çocuklar, dahil olduğu grup sayısı fazla olsa bile gruplar tarafindan tam anlamıyla kabul edildiğini hissedememesi, kabul alt boyutu ile olan negatif ilişkiyi ve vazgeçilmez hissedememesi reddedilme boyutu ile olan pozitif ilişkiyi açıklamaktadır.

Öğretmenler, akranlar ve ebeveynleri tarafindan desteklendiğini hisseden bireyler yüksek başa çıkma becerisine sahip olan bireyler olurlar (King, Vindourek, Davis ve McClellan, 2002, s. 294-299). Akademik yönden en az problem yaşayan (Eckstein vd., 2010, s. 408-434), aile desteğini kriz anlarında ihtiyaç duyulan bireyler görülmeleri nedeniyle ‘önemliyim ve yeterliyim' hissiyle doldurabilen büyük çocukların (Suitor ve Pillemer, 2007, s. 32-55) yüksek oranda aidiyet ihtiyacını karşılayabilen kişiler olarak düşünülmesi yanlış olmayacaktır.

Tek çocuklar ise pek çok kişilik özelliği bakımından büyük çocuklara benzeseler bile, aidiyet, işbirliği, paylaşımcılık ve mükemmelliyetçilikte abartılılık açılarından büyük çocuklardan ayrılmaktadır (Leman, 1997). Özellikle bir gruba ait olma ihtiyacı en az olan doğum sırası pozisyonu tek çocuklara aittir (Eckstein 
vd., 2010, s. 408-434). Aidiyet ve sevgi ihtiyacı hem sevgi vermeyi hem de almayı içermektedir (Feist ve Feist, 2006) ve tek çocuklar daha bencil oluşlarıla, hata kabul etmeyen abartılı mükemmelliyetçilikleriyle (Leman, 1997), gruplar tarafından en az uzlaşılabilir ve uyumsuz bireyler olarak görülmeleriyle (Herrera vd., 2003, s. 142-150) karakterize olmuş bireylerdir.

Yalnızlık ve sosyal destek ilişkisini açıklamaya yönelik yapılmış bir araştırmaya göre, öğrencilerin sosyal bağılık, arkadaş desteği, aile desteği ve özel insan desteği arttıkça yalnızlık duygusu azalmaktadır. Ek olarak, uyum sorunları ile yalnızlık arasında pozitif yönde anlamlı bir ilişki olduğu sonucu literatürde yer almaktadır (Duru, 2008, s. 13-24). Bu araştırmanın bulguları, aile, arkadaş, romantik ilişki ve uyum problem alanları ile ortanca ve tek çocuğun pozitif ilişkili olduğunu göstermektedir. Ayrıca yapılan bir başka araştırma küçük çocukların kendisinden büyük kardeş desteğine sahip olmasıyla aidiyet düzeyleri arasında olumlu bir ilişki olduğunu göstermektedir (Hollifield ve Cogner, 2015, s. 143-153). Bu sonuçlar da dikkate alınarak ortanca ve tek çocukların düşük aidiyet duygusu olan bireyler oldukları, büyük ve küçük çocukların ise yüksek aidiyet duygusu olan bireyler oldukları sonucuna varılabilmektedir.

\section{Gerçek ve Psikolojik Doğum Sırası ile Öz anlayış}

Araştırmada öz anlayışın gerçek doğum sırasına göre farklılaşmadığı ancak psikolojik doğum sırasına göre büyük çocuk olan bireylerin öz anlayış puan ortalamalarının ortanca olanlardan ve psikolojik doğum sırası küçük çocuk olan bireylerin öz anlayış puan ortalamalarının ortanca ve tek çocuk olanlardan daha yüksek olduğu bulunmuştur.

Öz anlayış, öz yargılamanın, izolasyonun ve ruminasyonun (depresyon gibi) olumsuz sonuçlarına karşı bireyleri koruyan pozitif duygusal tutumu ifade eder (Neff, 2003a, s. 85-101). Aynı zamanda hayatta karşımıza çıkabilecek olumsuz durumlara yönelik negatif duygu üretilse bile bunu şefkatle kabul ederek yeni olumlu duygular üretilmesini sağlayan önemli bir öz tutumdur (Germer ve Neff, 2013, s. 856-867). Öz anlayışlı bireyler başarısızlıktan daha az korkarlar (Neff vd., 2005, s. 263-287). Öz anlayışlı bireyler sergiledikleri performansları kişiselleştirmeden değerlendirebilen, gerçekçi değerlendirme yapabilen bireylerdir (Neff vd., 2005, s. 263-287). Yapılan araştırmalar öz anlayış ile yaşam doyumu, sosyal bağ, duygusal zeka, mutluluk, refah arasında pozitif ilişki olduğunu gösterirken, kaygı, depresyon, utanç, başarısızlık korkusu ve tükenmişlik ile negatif ilişkili olduğunu göstermektedir (Bernard ve Curry, 2011, s. 289-303; Mills vd., 2007, s. 358-364; Neff vd., 2005, s. 263-287; Neff vd., 2007, s. 908-916 ;Neff ve Mcgeehee, 2010, s. 225-240; Williams vd., 2008, s. 37-44). Ayrıca öz anlayış ustalık hedefleriyle, duygularla, bireylerin etkileşim şekilleriyle pozitif yönde ilişkilidir ve performans hedefleri, başarısızlık durumuna ilişskin kişilerin gösterdikleri tutumlarla, uyumsuz başa çıkma stratejileriyle, uyumsuz mükemmelliyetçilikle, düşünce baskılama ve ruminasyonla negatif yönde ilişkili bulunmuş oldukça önemli bir öz tutumdur (Leary vd., 2007, s. 887-904; Neff vd., 2005, s. 263-287; Neff, 2003a, s. 85-101; William vd., 2008, s. 37-44; Thompson ve Waltz, 2008, s. 556-558) Özellikle ailelerin yaklaşım şekli çocukların iç diyaloglarına yansıyarak, öz anlayışı etkilemektedir (Neff ve Mcgeehee, 2010, s. 225-240). Bu geniş kapsamdan bakılarak araştırma bulguları değerlendirildiğinde, psikolojik doğum sırası konumu büyük ve küçük çocuk olan bireylerin diğer psikolojik doğum sırası konumlarına göre daha fazla öz anlayışa sahip olmaları, araştırma sonuçlarının psikolojik doğum sırası literatürüyle tutarlı bir sonuca ulaştığını göstermektedir. Büyük çocuklar, sorumluluk sahibi, öz güveni yüksek (Sulloway, 1997), başkalarının bakım ve ihtiyaçlarıyla ilgilenen (Feist ve Feist, 2006), yüksek motivasyonlu ve stresli durumlarda etkin çözüm becerisine sahip (Eckstein, 2000, s. 481-494; Eckstein vd., 2010, s. 408-434) bireylerdir.

Şefkatli bireyler başarısızlıktan daha az korkarlar. Başarısızlık karşısında vazgeçmek yerine yeniden denemek eğiliminde olurlar (Neff vd., 2005, s. 263-287). Ustalık hedefi yönelimli bireyler olan büyük çocuklar kendi yeteneklerini ve performaslarını değerlendirirken içsel motivasyonu kullanan, performanslarını iyileştirmeye motive olmuş, öz nitelikleri referans alan bireylerdir (Carette, Anseel ve Yperen, 2011, s. 500-503) ve bu yönüyle büyük çocuklar başarısızlık durumunda öz anlayışı yüksek kalabilen bireylerdir. Çünkü büyük çocuklar iyi performans sergiledikleri durumları da kötü performansta olduğu gibi kendi öz niteliklerinden kaynaklandığına inanarak, daha fazla kişisel sorumluluk yüklenmektedirler (Phillips ve Phillips, 2000, s. 474-480).

Küçük çocuklar ise sosyal yönden en çok kabul gören, empati kurma konusunda başarllı ve sosyal yönden ilgi alan bireylerdir (Eckstein vd., 2010, s. 408-434). Ailenin en küçük bireyi olmak, diğer kardeşlerin yaşadıkları stres verici olayları nasıl algıladıklarını, ve nasıl başa çıktıklarını gözlemleyebilme şansı tanımaktadır. Ortak paydaşım bakış açısı geliştirmelerini kolaylaştırmaktadır çünkü kendi başlarına gelebilen olumsuz bir durum, başkalarının da başına gelebilir, kişiselleştirmeden, kendilerine acımadan 
olumsuz duyguları yaşamaları böylece kolaylaşmaktadır. Duygusal esneklik ile öz anlayış bu açıdan ilişkili görünmektedir (Germer, 2018). Empati yönünün kuvvetli oluşu yine olumsuz duygularla başa çıkmalarını ve kendilerine yönelik iç seslerini yumuşatmaya katkı sağlamaktadır. Yapılan bir araştırma, bireylerin kişilik özellikleri ile öz anlayış arasındaki ilişkiyi araştırmışıı ve dışadönüklük, sorumluluk, deneyime açıklık, yumuşak başlılık alt boyutları ile öz anlayışın pozitif yönde iliş̧kili olduğu sonucuna varmıştır (Özyeşil, 2011). Bu yönlerden ele alındığında öz anlayışın büyük ve küçük çocuk özellikleriyle pozitif yönde ilişkili olması alanyazınıyla tutarlı bir bulgu olarak görülmektedir.

Ortanca çocuk olan bireyler ve tek çocuk olan bireyler ise öz anlayışla negatif ilişkili bulunmuştur. Ortanca çocuklar işbirlikçi ve yüksek motivasyonludur (Feist ve Feist, 2006), ancak aynı zamanda sosyal yönden kendilerini kardeşleriyle ve başkalarıyla kıyaslama yönelimleri de oldukça fazladır (Adler, 2018). Öz anlayış, bireylere sosyal karşılaşıırmaya karşı güçlü bir koruma sağlar (Neff ve Mcgehee, 2010, s. 225-240). Ortanca çocukların sahip olduğu bu kıyaslama eğilimi zaman zaman kendilerine yönelik iç diyaloglarına da olumsuz yansıyarak, öz anlayışlarını düşürmektedir. Çünkü öz anlayış başkalarıyla kıyas yapmak yerine algılanan başarısızlık ya da yetersizlik durumlarında bile bireylerin kendileriyle bağ kurmalarını ve kendilerine böyle anlarda nazik, açık görüşlü yaklaşabilmelerini gerektirmektedir (Neff, 2011, s. 1-12).

Öz anlayış yüksek benlik saygısı gibi bireylere bilişsel fayda sağlayabilen bir öz tutumdur (Neff, 2011, s. 1-12). Öz anlayış yalnızca işler ters gittiğinde koruyucu değildir, aynı zamanda, bireylerin kendilerini bağll, değerli ve kabul edilebilir hissetme konusunda da önemli, benzersiz bir rol oynadığ1 görülmektedir (Neff ve Vonk, 2009, s. 23-50). Ortanca çocuklar öz saygısı daha düşük bireyler olarak düşünülmektedir ve bunun sebebi, algılanan aile desteğinin daha az olması ve arkadaş grubu gibi sosyal alanlarda kabul edilmeye verdikleri yüksek önemle ilişkili olabileceği görüşüne dayandırılmaktadır (Kalkan ve Koç, 2007, s. 45-59). Bu açıdan öz anlayışın ortanca çocuk özelliklerinin artmasıyla negatif ilişkili olması tutarlı bir bulgu olarak değerlendirilebilmektedir. Tek çocuklar yetişkin yönelimli bireylerdir ve abartılı üstünlük çabası içine girebilmektedirler (Feist ve Feist, 2006). Sosyal bağ açısından yoksun kalan, genellikle insanların kendilerini korumasını hatta şımartmasını isteyerek büyüdükleri belirtilmektedir (Feist ve Feist, 2006). Anne ve babanın referansları ve sosyal yönden korunma isteği iç sesin eleştirel olmasına ve hataya, başarısızlığa tahammülün azalmasına sebep olabilmektedir. Tek çocuklar büyük çocuklardan daha fazla mükemmelliyetçilik özellikleri taşırlar ve bu uyumsuz mükemmelliyetçilik bireylerin hayatla ve zorluklarla başa çıkmalarını zorlaştırmaktadır (Leman, 1997).

Öz anlayış uyumsuz mükemmelliyetçilik ile negatif ilişkili bir öz tutum becerisidir (Williams vd., 2008, s. 37-44). Düşük işbirlikçi yapıları nedeniyle (Eckstein vd., 2010, s. 408-434; Feist ve Feist, 2006), başkalarının hatalarına da kendisine olduğu gibi eleştirel yaklaşmalarına neden olmaktadır. Ortak paydaşım öz anlayışın önemli bileşenlerinden biridir ve insanoğlunun kusurlu olduğunu ve herkes gibi ac1 çekilebileceğini kabul edebilmeyi temel alır (Neff, 2003a, s. 85-101). Kendine veya başkalarına acımadan evrensel bir kabul ile insanı kabul etmektir. Psikolojik doğum sırasına ilişkin yapılan bir meta analiz araştırması, tek çocukların bencil bireyler olduklarını göstermektedir (Eckstein vd., 2010, s. 408-434). Ailede tek olmak, tüm kaynaklara da tek başına sahip olmayı beraberinde getirmektedir ve bu durum tek çocukların bencilleşmelerine neden olabilmektedir. Oysa öz anlayışta bireyler sahip oldukları ortak paydaşım bakış açısını ancak kendilerini ve başkalarını da içine alacak şekilde olayları kabul edebilmelerine dayandırabilirlerse mümkün olmaktadır (Germer ve Neff, 2013, s. 856-867).

\section{Gerçek ve Psikolojik Doğum Sırası ile Affetme}

Bir başka önemli araştırma konusu affediciliktir. Affetmenin gerçek doğum sırasına göre farklılaşmadığı ancak psikolojik doğum sırasına göre psikolojik doğum sırası büyük çocuk olan bireylerin puan ortalamasının, psikolojik doğum sırası tek çocuk olan bireylerin puan ortalamasından anlamlı düzeyde daha yüksek bulunmuştur.

Kardeş ilişkisinde çocuklar pek çok incinme yaşantısı içinde bulabilirler kendilerini ve birbirlerini affetmeyi yaşayarak öğrenirler. Hem affedici olmayı deneyimler kardeşler, hem de affedilmeyi. Bu yönden tek çocuklar, büyük çocuklardan ve diğer doğum sıralarından ayrılmaktadır (Adler, 2018 ; Leman,1997). Affediciliği kolaylaştıran bir diğer unsur ise kişinin kendi eksikliklerinin ve hatalarının farkında olup, affedilmesi gereken durum ya da kişiye yönelik cömert bir anlayıs duygusu geliştirebilmesine bağlıdır (Bono ve McCullough, 2006, s. 147-158). Kusursuz olmaya çalş̧an bireyler ikincilik olsa bile yine kendi performanslarının yeterliliğine inanır ve yükseltmek için motive olmaktadır. Oysa mükemmelliyetçiler kendilerini kazanmadıkları sürece asla yeterli görmez ve motivasyon aracı olarak kullanmazlar. 
Başardıklarına inanmak için birincilik şarttır (Leman, 1997). Kusursuz performansın peşinde koşan büyük çocuklarla, mükemmelliyetçi tek çocuklar hem öz anlayış açısından hem de affedicilik açısından bu noktalarda ayrılmaktadır. Mükemmelliyetçi özellikler taşıyan bireyler affedici olarak görülmemektedir (Leman,1997). Ayrıca bireylerin affetme düzeyleri arttıkça kaçınma motivasyonları azalmaktadır (McCollughg, Worthington Jr ve Rachal, 1997, s. 321-336). Tek çocuklar kaçınma stratejilerini kullanan bireylerdir ve yok sayma, görmezden gelme, uzaklaşma gibi problemin kaynağından sadece uzaklaşmalarını sağlayan başa çıkma tutumlarını kullanmaktadırlar (Kalkan ve Koç, 2007, s. 45-59). Kendi hatalarını ve kusurlu yanlarını kabul etmekte zorlanan mükemmelliyetçi tek çocuklar için ve kendine acıma eğilimi olan ortanca çocuklar için kendilerini affetmek, başkalarını affetmek ve olumsuz durumları affetmek daha zorlaşmaktadır. Kardeş desteğine sahip, sorumluluk duyguları yüksek ve kusursuz olmaya çalışan büyük çocuklar için (Leman, 1997) ve empati kuran, sosyal yönden ilgi alan ve korunan küçük çocuklar için kendine anlayışı olmak, etrafındaki kişilere anlayışı davranabilmek kolaylaşmaktadır ve dolayısıyla affedicilik düzeylerini de artırdığı düşünülmektedir.

\section{Sonuç, Sınırlıklar ve Gelecek Araştırmalar için Öneriler}

Araştırmanın bulguları, bireylerin yaşadıkları problem alanları, aidiyetleri, kendilerine gösterdikleri anlayış ve bir problemle karşılaşıtılarında affetme eğilimlerinde psikolojik doğum sırasının gerçek doğum sırasından çok daha belirleyici bir değişken olduğunu ortaya koymuştur. Görülmektedir ki; bireylerin öz kök ailelerinde kendilerini psikolojik olarak hangi pozisyonda gördükleri; kişilerarası ilişkilerinde hangi pozisyonda olduklarından daha çok önem taşımaktadır. Nitekim araştırmada gerçek doğum sırası ile psikolojik doğum sırası arasında anlamlı bir ilişki bulunmadığ1 görülmüştür. Bu çalşsma birbirinden bağımsız olan bireylerle yapılmıştır, sonraki çalışmalarda kardeşlerden oluşan bir örneklem grubu ile karşılaştırmalı çalışmalar yapilabilir.

Gerçek ve psikolojik doğum sırası üzerinde etkili görülen aile atmosferi, kardeş ve ebeveyn ilişkileri, travmatik yaşantılar, romantik ilişki deneyimleri gibi değişkenlerin araştırma konusuna dahil edilerek incelenmesi ileride yapılacak araştırmalar için önerilmektedir. Ayrıca aile tipi, kardeşler arası yaş farkı, kardeş cinsiyeti gibi değişkenler de kontrol edilerek çalışmalar yapılabilir.

Psikolojik doğum sırası bu araştırmada olduğu gibi birçok araştırmada gerçek doğum sırasından daha etkili bir değişken olduğu görülmesine rağmen, uygulayıcıların çok az dikkatini çekmiştir. Ruh sağlı̆̆1 alanında çalışan uzmanların özellikle aile dinamikleri ve bireyin içsel ve kişilerarası problemleri ile çalışıken psikolojik doğum sırasının da etkili bir dinamik olduğunu göz önünde bulundurarak psikolojik danışmanlık ve psikoterapide yol almalarının farklılaşma ve iyileşmeye katk1 sağlayacağ1 düşünülmektedir. Benzer şekilde, eğitim alanında çalışan uzmanların ögrencilere rehberlik sürecinde psikolojik doğum sırasının etkilerini dikkate almaları da önerilmektedir.

\section{Etik Beyan}

"Genel Aidiyet, Öz-Anlayıs, Affetme ve Problem Alanlarn Gergek ve Psikolojik Doğum Sirasina Göre Farklulaşır mı?" başlıklı çalışmanın yazım sürecinde bilimsel kurallara, etik ve alıntı kurallarına uyulmuş; toplanan veriler üzerinde herhangi bir tahrifat yapılmamış ve bu çalışma herhangi başka bir akademik yayın ortamına değerlendirme için gönderilmemiştir. Gerekli olan etik kurul izinleri Üsküdar Üniversitesi Girişimsel Olmayan Araştırmalar Etik Kurulu’nun 23.05.2018 tarih ve 06 sayılı toplantısında alınmıştır.

\section{Kaynakça}

Adams, B. N. (1972). Birth order: A critical review. Sociometry, 35(3), 411-439.

Adler, A. (2018). Insanı tanıma sanatı. Ankara: Tutku Yayınevi.

Andersen, S. M., Chen, S. ve Carter, C. (2000). Fundamental human needs: Making social cognition relevant. Psychological Inquiry, 11 (4), 269-275.

Argys, L. M., Rees, D. I., Averett, S. L., \& Witoonchart, B. (2006). Birth order and risky adolescent behavior. Economic Inquiry, 44(2), 215-233.

Bernard, L. K. ve Curry, J. F. (2011). Self-compassion: Conceptualizations, correlates and interventions. Review of General Psychology, 15(4), 289-303.

Bono, G. ve McCullough, M. E. (2006). Positive responses to benefit and harm: bringing forgiveness and gratitude into cognitive psychotherapy. Journal of Cognitive Psychotherapy: An International Quarterly, 20(2), 147-158.

Bugay, A., \& Demir, A. (2010). A Turkish version of hearthland forgiveness scale. Procedia Social and Behavioral Sciences, 5, 1927-1931.

Buunk, B. P. (1997). Personality, birth order and attachment styles as related to various types of jealousy. Personality and Individual Differences, 23(6), 997-1006. 
Campbell, L., White, J. ve Stewart, A. (1991). The relationship of psychological birth order to actual birth order. Individual Psychology: Journal of Adlerian Theory, Research and Practice, 47, 380-391.

Carette, B., Anseel, F. ve Van Yperen, N. W. (2011). Born to Learn or born to win? birth order effects on achievement goals. Journal of Research in Personality, 45, 500-503.

Carlson, J., Watts, R. E. ve Maniacci, M. (2006). Adlerian therapy: Theory and practice. Washington, DC: American Psychological Association.

Corey, G. (2015). Psikolojik danısma, psikoterapi kuram ve uygulamalar. Ankara: Mentis Yayıncilık.

Damian, R. I. ve Roberts, B. W. (2015). Settling the debate on birth order and personality. The National Academy of Sciences, 112(46), 14119-14120.

Davis, J. N. (1997). Birth order, ship size and status in modern canada. Human Nature, 8(3), 205-230.

Deniz, M. E., Kesici, Ş. ve Sümer, A. S. (2008). The validity and reliability of the Turkish version of the selfcompassion scale. Social Behavior and Personality, 36(9), 1151-1160.

Duru, E. (2008). Üniversiteye uyum sürecinde yalnızlı̆̆1 yordamada sosyal destek ve sosyal bağlllı̆̆ın doğrudan ve dolaylı rolleri. Türk Psikolojik Danısma ve Rebberlik Dergisi, 3(29), 13-24.

Duru, E. (2015). Genel aidiyet ölçeğinin psikometrik özellikleri: geçerlilik ve güvenilirlik çalışması. Türk Psikolojik Danısma ve Rebberlik Dergisi, 5(44), 37-47.

Eckstein, D. (2000). Empirical studies indicating significant birth-order-related personality differences. Individual Psychology, 56, 481-494.

Eckstein, D. ve Kaufman, J. A. (2012). The role of birth order in personality: An enduring intellectual legacy of Alfred Adler. The Journal of Individual Psychology, 68(1), 60-74.

Eckstein, D., Aycock, K. J., Sperber, M. A., McDonald, J., Wiesner, V. V., Watts, R. E. ve Ginsburg, P. (2010). A review of 200 birth order studies: Lifestyle characteristics. The Journal of Individual Psychology, 66(4), 408-434.

Fablo, T. ve Polit, D. F. (1986). Quantitative review of the only child literature: Research evidence and theory development. Psychological Bulletin APA, 100(2), 176-189.

Feist, J. ve Feist, G. J. (2006). Theories of personality (7th Edition). McGraw-Hill Primis.

Fergusson, D. M., Horwood, L. ve Boden, J. M. (2006). Birth order and educational achievement in adolescence and young adulthood. Australian Journal of Education, 50(2), 122-139.

Flowers, R. A. ve Brown, C. (2002). Effects of sport context and birth order on state anxiety. Journal of Sport Behavior, 25 (1), 41-56.

Germer, C. K. (2018). Özs sefkatli farkındahk. İstanbul: Diyojen Yayıncilık.

Germer, C. K. ve Neff, K. D. (2013). Self compassion in clinical practice. Journal of Clinical Psychology, 69(8), 856-867.

Gfroerer, K. P., Gfroerer, C. A., Curlette, W. L., White, J. ve Kern, R. M. (2003). Psycological birth order and the BASİ-A inventory. The Journal of Individual Psychology, 59(1), 30-41.

Greff, A. P. ve Malherbe, H. L. (2001). Intimacy and marital Satisfaction in Spouses. Journal of Sex and Marital Therapy, 27 (3), 247-257.

Gustafson, C. (2010). The effects of birth order on personality (Master Thesis). The Faculty of the Alfred Adler Graduate School, Minneapolis, ABD

Hall, J. H. ve Fincham, F. D. (2005). Self-forgiveness: The stepchild of forgiveness research. Journal of Social and Clinical Psychology, 24(5), 621-637.

Harthsorne, J. K., Salem-Hartshorne, N. ve Hartshorne, T. S. (2009). Birth order effects in the formation of long term relationships. Journal of Individual Psycology, 65, 156-176.

Herrera, N. C., Zajonc, R. B., Wieczorkowska, G. ve Cichomski, B. (2003). Beliefs about birth rank and their reflection in reality. Journal of Personality and Social Psychology, 85(1), 142-150.

Hill, D. L. (2006). Sense of belonging as connectedness, American Indian worldview and mental health. Archives of Psychiatric Nursing, 20 (5), 210-216.

Hollifield, C. R. ve Cogner, K. J. (2015). The role of siblings and psychological needs in predicting life satisfaction during emerging adulthood. Emerging Adulthood, 3 (3), 143-153.

Horner , P., Andrade, F., Delva, J., Grogan-Kaylor, A. ve Castillo, M. (1998). The relationship of birth order and gender with academic standing and substance use among youth in Latin America. Journal of Individual Psychology, 68(1), 19-37.

Ickes, W. ve Turner, M. (1983). On the social advantages of having an older, opposite-sex sibling: birth order influences in mixed sex dyads. Journal of Personality and Social Psychology, 45(1), 210-222.

Kalkan, M. (2005). White Campbell psikolojik doğum sırası envanterinin geçerlilik ve güvenilirlik çalışması. Psikiyatri Psikoloji Psikofarmakoloji Dergisi, 13(3), 169-174.

Kalkan, M. (2008). The relationship of psychological birth order to 1rrational relationship beliefs. Social Behavior and Personality, 36(4), 455-466.

Kalkan, M. ve Koç, H. (2007). psikolojik doğum sırası bireylerin stresle başa çıkma stratejilerinin yordayıcısı mıdır? Türk Psikolojik Danısma ve Rebberlik Dergisi, 3(30), 45-59.

King, K. A., Vidourek, R. A., Davis, B. ve McClellan, W. (2002). Increasing self-esteem and school connectedness through a multidimensional mentoring program. Journal of School Health, 72(7), 294-299.

Laird, T. G. ve Shelton, A. J. (2006). From an adlerian perspective: Birth order, dependency, and binge drinking on Historically Black University campus. The Journal of Individual Psychology, 62(1), 18-35. 
Leary, M. R., Tate, E. B., Adams, C. E., Allen, A. B. \& Hancock, J. (2007). Self compassion and reactions to unplesant self-relevant events: the implications of treating oneself kindly. Journal of Personality and Social Psychology, $92(5), 887-904$.

Leman, K. (1997). Doğuşs sirası. İstanbul: Kuraldışı Yayıncilık.

Leman, K. (2011). Kąanmak için doğanlar. İstanbul: Final Kültür Sanat Yayınları.

Lohman, J. F., Lohman, T. G. ve Christensen, O. (1985). Psychological position and perceived sibling differences. Individual Psychology, 41(3), 313-327.

Malone, G. P., Pillow, D. R. ve Osman, A. (2012). The general belongingness scale (GBS): Assessing achieved belongingness. Personality and Individual Differences, 52, 311-316.

Maslow, A. H. (1970). Motivation and personality (2nd Edition). New York: Harper\& Row.

McCollugh, M. E., Worthington Jr., E. L. ve Rachal, K. C. (1997). Interpersonal forgiving in close relationships. Journal of Personality and Social Psychology, 73(2), 321-336.

McGurik, E. M. ve Pettijohn II, T. F. (2008). Birth order and romantic relationship styles and attidues in collage students. North American Journal of Psychology, 10(1), 37-52.

Mills, A., Gilbert, P., Bellew, R., McEwan, K. ve Gale, C. (2007). Paranoid beliefs and self-criticism in students. Clinical Psychology and Psychotherapy, 14, 358-364.

Neff, K. (2003 b). The development and validation of a scale to measure self-compassion. Self and Identity, 2(3), 223250.

Neff, K. (2003a). Self-compassion: An alternative conceptualization of a healthy attitude toward oneself. Self and Identity, 2(2), 85-101.

Neff, K. D. (2011). Self compassion, self esteem and well-being. Social and Personality Psychology Compass, 5(1), 1-12.

Neff, K. D. ve McGehee, P. (2010). Self compassion and psychological resilience among adolescents and young adults. Self and Identity, 9(3), 225-240.

Neff, K. D. ve Pommier, E. (2013). The relationship between self-compassion and other-focused concern among college undergraduates, community adults and practicing meditators. Self and Identity, 12(2), 160-176.

Neff, K. D. ve Vonk, R. (2009). Self compassion versus global self esteem: two different ways of relating to oneself. Journal of Personality, 77(1), 23-50.

Neff, K. D., Hsieh, Y. P. ve Dejitterat, K. (2005). Self-compassion, achievement goals, and coping with academic failure. Self and Identity, 4, 263-287.

Neff, K. D., Rude, S. S., \& Kirkpatrick, K. L. (2007). An examination of self-compassion in relation to positive psychological functioning and personality traits. Journal of Research in Personality, 41, 908-916.

Osterman, K. F. (2000). Students' need for belonging in the school community. Review of Educational Research, 70(3), 323-367.

Özyeşil, Z. (2011). Öz-anlayıs ve bilinçli-farkındahk. Ankara: Maya Akademi Yayınevi.

Phillips, A. S., \& Phillips, C. R. (2000). Birth order differences in self- attributions for achievement. The journal of Individual Psychology, 56(4), 474-480.

Pilkington, L., White, J. ve Matheny, K. B. (1997). Percieved coping resources and psychological birth order in school aged childeren. Individual Psychology, 53(1), $42-57$.

Rohrer, J. M., Egloff, B. ve Schmukle, S. C. (2015). Birth order effects on personality. Proceedings of the National academy of Sciences, 112(46), 14224-14229.

Salmon, C. (2003). Birth order and relationships. Human Nature, 14(1), 73-88.

Salmon, C. A. ve Daly, M. (1998). Birth order and familial sentiment: middleborns are different. Evolution and Human Behavior, 19, 299-312.

Shulman, B. H. ve Mosak, H. H. (1977). Birth order and ordinal position: two adlerian views. Journal of Individual Psychology, 33, 114-121.

Stewart, A. E. ve Campbell, L. F. (1998). Validity and reliabilty of the white campbell psychological birth order inventory. Journal of Individual Psychology, 54(1), 42-60.

Stewart, A. E., Stewart, E. A. ve Campbell, L. F. (2001). The relationship of psychological birth order to the family atmosphere and to personality. The Journal of Individual Psychology, 57(4), 363-387.

Suitor, J. J. ve Pillemer, K. (2007). Mothers' favoritism in later life. Research on Aging, 29(1), 32-55.

Sullivan, B. F. ve Schwebel, A. I. (1996). Birth-order position, gender, and 1rrational relationship beliefs. Individual Psychology, 52, 55-64.

Sulloway, F. J. (1997). Born to rebel: Birth order, family dynamics and creative lives. New York: Vintage Books- Random House Inc.

Sulloway, F. J. (2001). Birth order and sibling competition and human behavior. Conceptual Challenges in Evolutionary Psychology (s. 39-83). içinde Studies in Cognitive Systems.

Thompson, B. L. ve Waltz, J. (2008). Self compassion and PTSD symptom severity. Journal of Traumatic Stress, 21(6), 556-558.

Thompson, L. Y., Snyder, C. R., Hoffman, L., Michael, S. T., Rasmussen, H. N., Billings, L. S., et al. (2005). Dispositional forgiveness of self, others and situations. Journal of Personality, 73(2), 313-360.

Trommsdorff, G. (1983). Future orientation and socialization. International Journal of Psychology, 18(1/4), 381-406.

White, J., Campbell, L., Stewart, A., Davies, M. ve Pilkington, L. (1997). The relationship of psychological birth order to career interests. Individual Psychology, 53(1), 89-104. 
Williams, J. G., Stark, S. K. ve Foster, E. E. (2008). Start today or the very last day? The relationship among selfcompassion, motivation and procrastination. American Journal of Psychological Research, 4, 37-44.

Worthington Jr., E. L. ve Scherer, M. (2004). Forgiveness in an emotion-focused coping strategy that can reduce health risks and promote health resilience: Theory, review and hypotheses. Psychology and Health, 19(3), 385-405.

Yildırım, A. (1997). Gender role influences on Turkish adolescents self identity. Adolescence, 32(125), $217-231$.

\section{EXTENDED ABSTRACT}

The aim of the study was to examine the relationship between the actual birth order and the psychological birth order of the individuals, in other words, whether it psychologically protects the real birth order in the family system. Moreover, the purpose was to examine whether the areas, where individuals have problems, differ according to their actual birth order and psychological birth order. It is assumed that the strategies of coping with the problems individuals face, especially in interpersonal relationships, will differ according to the actual and psychological birth order. For this reason, one of the main purposes of the study is to present whether self-compassion, general belongingness and forgiveness differ according to actual and psychological birth order.

The study group consisted of 403 participants who agreed to participate voluntarily. $261(64.8 \%)$ of the participants of the study group were female and $142(35.2 \%)$ of the participants were male. When the actual birth order of the study group was examined, $33.7 \%$ were oldest children, $21.1 \%$ were middle children, $38.2 \%$ were youngest children and $6.9 \%$ were only child. The mean age of the study group is 35.20. The first section of the personal information form contains questions about gender, age, education status and actual birth order. The second section of the form contains 10 questions for identifying problem areas of individuals. In this section, participants were asked to mark problems that they experienced in the past and that they thought these problems were effective for a certain period of time considering their entire lives. The problem areas in the form include academic, family, friend, economic, romantic relationships, emotional area, personality area, sexuality, smoking/drug/alcohol use and adaptation area. Self-Compassion Scale (Neff, 2003b), Psychological Birth Order Inventory (White, Campbell and Stewart, 1991; 1998), General Belongingness Scale (Malone et al., 2012) and the Heartland Forgiveness Scale (Thompson et al., 2005) were used as data collection tools in the study.

First of all, the relationship between the actual birth order and the psychological birth order of the individuals was tried to be determined. Whether it psychologically protected the birth order actually existing in the family system was examined. According to the results, there was no significant relationship between actual birth order and psychological birth order ( $p>.05)$. When whether the problem areas differed according to the actual and psychological birth order was examined, it was found that problem areas did not differ according to the actual birth order in academic, family, friendship, economic, smoking/drug/alcohol use, personality, sexuality and adaptation problem areas ( $\mathrm{p}>.05)$ whereas oldest and only individuals had more emotional problems $(\mathrm{p}<.05)$. Accordingly, while $32.9 \%$ of the middle individuals and $35.1 \%$ of the youngest individuals stated that they had experienced emotional problems, $50 \%$ of only individuals and $47.8 \%$ of oldest individuals stated that they had experienced emotional problems. While examining the relationship between psychological birth order and problem areas, it was concluded that according to their psychological birth order, psychologically middle individuals $(\mathrm{p}<.05)$ and psychologically only individuals $(\mathrm{p}<.01)$ experienced more academic problems. When the results were considered in terms of the family problem area, the psychological birth order oldest children score averages of the individuals experiencing family problems were significantly higher than those not experiencing $(\mathrm{p}<.05)$. The middle children score averages and single children score averages were significantly higher than those not experiencing the problems $(\mathrm{p}<.001)$. Moreover, psychological birth order youngest children score averages of individuals experiencing family problems were found to be significantly lower than those not experiencing $(\mathrm{p}<.01)$.

When the results were evaluated in terms of the problem area of friendship, it was found that psychologically middle individuals faced more problems than other psychological birth orders $(p<.01)$. When the results of the problem area of economics were psychologically oldest individuals experienced less economic problems $(\mathrm{p}<.05)$. When the results in emotional problem area were examined, the score averages of individuals, oldest and middle children according to their psychological birth order were found to be significantly higher than other psychological birth order score averages $(\mathrm{p}<.01)$. Psychologically only individuals experienced more problems related to smoking/alcohol/drug use than other birth order positions $(\mathrm{p}<.01)$. The psychological birth order position that experiences the least problems related to 
smoking/alcohol/drug use was the psychologically oldest individuals $(\mathrm{p}<.01)$. In the romantic relationship problem area, psychologically middle and only individuals were found to experience more problems $(\mathrm{p}<.01)$. Besides, psychologically middle $(\mathrm{p}<.001)$ and only individuals $(\mathrm{p}<.05)$ were found to experience more personality problems. In the sexuality problem area, it was found that psychologically middle and single individuals experienced more problems $(\mathrm{p}<.05)$. When the results were evaluated in terms of adaptation problem area, it was concluded that individuals psychologically middle individuals experienced more problems in situations such as adaptation to new environment, school or work $(p<.001)$.

Another concept addressed in the present study is the feeling of general belongingness. It is seen that the belonging scores of individuals do not differ according to the actual birth order ( $\mathrm{F}=.933 ; \mathrm{p}>.05)$ however, psychologically oldest and youngest individuals have significantly more general belongingness score average psychologically middle and only individuals $(\mathrm{p}<.001)$. On the other hand, it was found that self-compassion did not differ according to actual birth order $(\mathrm{F}=1.631 ; \mathrm{p}>.05)$ whereas the selfcompassion score averages of psychologically oldest individuals, were higher than psychologically middle individuals $(\mathrm{p}<.01)$ and self-compassion score averages of psychologically youngest individuals, were higher than psychologically middle $(\mathrm{p}<.001)$ and psychologically only individuals $(\mathrm{p}<.05)$. Another important research topic is forgiveness. A statistically significant result was obtained from the one-way analysis of variance (ANOVA) for forgiveness scale total score averages of groups according to the actual birth order $(\mathrm{F}=2.847 ; \mathrm{p}<.05)$ however, no significant results were obtained from the Scheffe Test Results for Heartland Forgiveness Total Score Averages according to the actual birth order. Forgiveness did not differ according to the actual birth order. A statistically significant result was obtained when the results were examined according to psychological birth order $(\mathrm{F}=3.657 ; \mathrm{p}<.05)$. Accordingly, the total forgiveness score average of psychologically oldest individuals were found to be significantly higher than the score average of psychologically only individuals $(\mathrm{p}<.05)$.

The results of the present study have revealed that psychological birth order is a much more decisive variable than the actual birth order in their tendency to forgive when they face a problem, and in terms of their belonging and self-compassion in the problem areas. It is observed that the position where individuals see themselves psychologically in their families is more important than the position where they are in interpersonal relationships. Although many studies found it to be a more effective variable than actual birth order as in this study, psychological birth order has attracted the attention less attention from the implementers. Considering that the psychological birth order is an effective dynamic for the professionals in the mental health, especially when working on family dynamics and internal and interpersonal problems, it is believed that advancing in psychological counseling and psychotherapy will contribute to the improvement and differentiation. Similarly, experts working in the field of education are also recommended to consider the effects of psychological birth order in the process of guiding students. 